\title{
Kırk Vezir Hikâyeleri Minyatürleri Üzerine Bir İnceleme
}

\author{
A Study on The Miniatures of Forty Viziers' Stories
}

\author{
Hesna Haral ${ }^{\star}$
}

Öz

Bu makale, Kırk Vezir Hikâyeleri isimli bir Osmanlı eserinin minyatürlü iki nüshasını tanıtmakta ve bu iki nüshanın resimlerine ilişkin ikonografik bir değerlendirme sunmaktadır. İlk nüsha tarihsizdir ve bugün İstanbul Üniversitesi Kütüphanesi’nde [iü T. 7415] kayıtıdır. Eser III. Selim'in vakıf mührünü taşımaktadır ve içerisinde on iki minyatür bulunmaktadır. Diğer nüsha İsveç'te Uppsala Üniversitesi Carolina Rediviva Kütüphanesi'nin Türkçe yazma eserleri [UUL Vet. 38] arasındadır. 1586-1587 (H.995) tarihli bu nüshanın kâtibi Muhammed bin Mustafa'dır ve kitapta on yedi minyatür vardır. Nasihatname türündeki Kırk Vezir Hikâyeleri Osmanlı sarayında okunan bir eserdir. Eserin her iki nüshasındaki minyatürler, Osmanlı klasik minyatür üslubundadır ve Nakkaş Osman yolunda çalışan iki sanatçının elinden çıkmıştır. 1580'li yıllara tarihlendirilebilecek İstanbul nüshası ve 1586-1587 tarihli Uppsala nüshasının Sultan III. Murad (1574-1595) döneminde Osmanlı sarayı için hazırlanmış olması ihtimal dâhilindedir.

Osmanlı resminde nasihatname türünün örneklerini temsil eden Kırk Vezir Hikâyeleri minyatürleri, bilgeliğin simgesi kırk vezir ve hilebazlığı temsil eden kadın karakterler tarafından anlatılan ve sonu bir nasihatle tamamlanan öyküleri konu etmektedir. Her iki nüshanın tasvirleri, Hz. Musa ile Uç bin Unk'un mücadelesi ve bir Osmanlı Sinbadnâmesi'nde de yer bulan bir minyatür hariç, ikonografik açıdan özgündür. Minyatürler arasında Gazneli Sultan Mahmud ve onun has adamı Ayaz'ı, İşrakî felsefenin temsilcisi Şeyh Sühreverdi-i Maktül'ü ve filozof İbn Sina'yı gösteren sahneler, İslam resmine yeni ikonografya ve imgeler sunmaktadır.

\section{Anahtar Kelimeler}

Kırk Vezir Hikâyeleri Minyatürleri, İkonografi, Resimli Osmanlı Nasihatnamesi, Osmanlı Minyatür Sanatı

\begin{abstract}
This article aims to introduce two illustrated copies of an Ottoman manuscript under the title Stories of Forty Viziers. One of these copies is now registered in the Istanbul University Library [IU T. 7415]. It has twelve miniatures and no colophone. The other copy is among the Turkish Manuscripts of Uppsala University's Carolina Rediviva Library [UUL Vet. 38]. The colophone date is 1586-1587 (H.995) and it has seventeen miniatures. Stories of Forty Viziers was one of the books read in the Ottoman Palace. Although there are studies on the text and copies of the book in the field of Turkish literature, there is no study about the iconographies of the miniatures in them. The miniatures in the two copies of Stories of Forty Viziers are in Ottoman Classical Painting Style. The undated Istanbul manuscript [IU T. 7415] could be estimated to the 1580 s and the colophon date of the Uppsala copy of the manuscript of 1586-1587 is already in the culmination of the classical painting style which is the period of Ottoman Sultan Murad III (1574-1595).The painters of the two copies had clearly worked in the way of Nakkash Osman who was the leading painter of Ottoman classical painting.
\end{abstract}

The miniatures of Stories of Forty Viziers represent the Otttoman advice letters iconography and with the exception of two, all the other miniatures are unique iconographically. One of two is about the combat between the prophet Moses

* Sorumlu Yazar: Hesna Haral (Dr. Öğr. Üyesi), Nişantaşı Üniversitesi, Sanat Tasarım Fakültesi, İç Mimarlık Bölümü (İng.), İstanbul, Türkiye. E-posta: hesna.haral@nisantasi.edu.tr ORCID: 0000-0003-2205-4723

Atıf: Haral, Hesna. “Kırk Vezir Hikâyeleri Minyatürleri Üzerine Bir İnceleme." Art-Sanat, 13 (2020): 205-243. https://doi.org/10.26650/artsanat.2020.13.0009 
and Giant Og and the other is from Ottoman Sinbad-nama. In the miniatures the stories depict the struggle between characters representing wisdom (forty viziers) and deception (wife). Additionally the miniatures about Sultan Mahmud of Ghazni, Ishraqi Philosopher Suhrawardi al-Maqtul and Ibn Sina (Avicenna) represent new images and new iconographies.

Keywords

Illustrated Copies of Forty Viziers, Miniatures of Forty Viziers, Iconography, Illustrated Ottoman Nasihatname (Advice Letters), Ottoman Miniature Painting

\section{Extended Summary}

This article aims to introduce two illustrated copies of an Ottoman manuscript under the title of Stories of Forty Viziers. One of these copies is now registered in Istanbul University's Library [IU T. 7415]. It has twelve miniatures and no colophone. This copy has a seal of Sultan Selim III. The other copy is among the Turkish Manuscripts of Uppsala University's Carolina Rediviva Library [UUL Vet. 38]. The colophone date is between 1586-1587 (H.995) and it has seventeen miniatures. Although there are studies on the text and copies of the book in the field of Turkish literature, there is no study about the iconographies of the miniatures in these two illustrated manuscripts.

Stories of Forty Viziers is a translation from an Arabic work entitled Hikayat-i Erbain-i Subh u Mesa. The first translations come from XVth century. One of them belongs to Ahmed-i Misrî and it was presented to Sultan Murad II (1421-1451) in 1446. The book was reorganized by Sheikzadeh and presented to both Sultan Murad II and Sultan Mehmed II. Although different opinions have been put forward about the original source of the book, the "frame story" of the book is similar to Sinbad Namah (Seven Viziers). Stories of Forty Viziers was one of the books read in the Ottoman Palace like Kalila and Dimna, Humayun-nama and One Thousand Nights to train the young members of the palace about customs, certain types of attitudes and languages.

Stories of Forty Viziers is written in a "frame story" narrative form, meaning that there is a main story and short stories positioned within a main one. According to the frame story, one day the master sees a bad fortune in the horoscope of Acem king Cefakan's shahzade and warns him not to talk even a word for forty days in order to avoid his future misfortune. The Shah is very upset about his son's silence and sends him to his step mother. The Shah's young wife is already in love with shahzade and wants him. She tells a plan about killing the shah and replacing him in his place. Shahzade refuses her love and her plan. Then she accuses shahzade in the presence of Shah Cefakan for trying to have her. She convinces the shah in order to kill his son. The forty viziers want to change the shah's idea by telling stories about how women are inreliable and deceitful during the mornings of forty days. When it comes to nights, the wife tells stories ending up with an idea how the shah would regret it if he trusts his viziers and would not kill his son. At the end of forty days, when the shah puts his son in front of an executioner, the master of shahzade comes in and 
tells him that he was the person who advised him not to talk until the bad fortune vanished. Shahzade tells everything and frees him from death. The frame story of the book which symbolizes the struggle between the characters representing wisdom (forty viziers) and deception (wife), also includes the nested stories about prophets, well-known mystics, philosophers and kings. Generally these stories end up being an advice about choosing a good and wise manner.

The miniatures in the two copies of Stories of Forty Viziers are in the Ottoman Classical Painting Style. The colophon date of the Uppsala copy of the manuscript of 1586-1587 is already in the culmination of the classical style which is the period of Ottoman Sultan Murad III (1574-1595). In an earlier study, the undated Istanbul manuscript is already estimated to have been created in the $1580 \mathrm{~s}$. Thanks to great similarities of stylistic features and iconographies of illustrations between the Istanbul and Uppsala manuscripts which are investigated in this article, the Istanbul manuscript [IU T. 7415] can be strongly estimated to having been produced in the1580s. The painters of both copies surely had worked in the way of Nakkash Osman who was the leading painter of the Ottoman classical painting. The illustration of both copies have resemblances especially with the miniatures of Surnama-i Humayun and Javahir al Ghraib Tarjomat Bahr al-Ajaib, both of which are dated to 1582. Both copies were painted by two different artists. The painter of the Istanbul copy is called Nakkash A and the painter of the Uppsala copy is Nakkash B. Although the illustrations of the Uppsala copy were retouched, the artistic talents of both painters are obvious. These two illustrated copies of Stories of Forty Viziers are likely to have been prepared in the reign of Sultan Murad III (1574-1595) for the Ottoman palace.

Most of the miniatures in the two copies of the manuscripts are unique iconographically. Two miniatures in both copies share the common iconographies in Islamic miniature painting. One of them is about the combat between the prophet Moses and Giant $\mathrm{Og}$ and the other one is from Ottoman Sinbad-nama which is about a wife (or a concubine) who openly shows her desire for the young shahzade. But all the other miniatures of Stories of Forty Viziers present new iconographies to the Islamic art. In both manuscripts ten miniatures are mutual. The subjects of these miniatures are the desire and the attempt of Shah Cefakan's wife to win shahzade, the wife's accusation before the shah, Philosopher Suhrawardi al-Maqtul punishing the unfaithful sultan of Egypt the murder of Suhrawardi al-Maqtul by the men of sultan, the combat between Og and Moses, a vizier bringing a young lover of a sultan, a dog hurting one of the seven immortal, the women of Turkish nomads lamenting, Amir Semhul and his man watching a falcon and a parrot judging a woman. The miniatures in Stories of Forty Viziers present Sultan Mahmud of Ghazni, Ishraqi Philosopher Suhrawardi al-Maqtul and Ibn Sina (Avicenna) to the Ottoman elite in new images and new iconographies. The miniatures of Stories of Forty Viziers represent the Otttoman advice letters iconography. 


\section{Giriş}

Kırk Vezir Hikâyeleri, çerçeve hikâye geleneğine göre kaleme alınmış bir eserdir. "Çerçeve öykü" veya "öykü içinde öykü" olarak da isimlendirilen bu anlatım formu, bir ana hikâye içinde başka bir hikâyenin veya hikâyelerin konumlandırılmasıyla oluşmaktadır. ${ }^{1}$ Kırk Vezir Hikâyeleri'nde çerçeve hikâyenin ana kahramanları: Acem mülkünde bir padişah olan Şah Cefekân, bu şahın genç hatunu, şahın eski eşinden doğan şehzadesi, şehzadeye ilm-i nücûm (yıldızlar ilmi) ve ilm-i heyet (astronomi) öğreten üstadı ve şahın kırk veziridir. Üstat, şehzadenin falında bir uğursuzluk görür. Bu uğursuzluktan kurtulabilmesi için, ona başının üzerinde kılıç bile sallansa, kırk gün boyunca tek bir kelime dahi etmemesini tembihler. Şah, şehzadenin konuşmadığını görünce onu (üvey) annesine yollar. Hatun, şehzadeye âşık olduğundan, firsatı ganimet bilir ve şehzadeye gayrimeşru ilişki teklif eder. Bu ahlaksız davranış üzerine şehzade hatuna vurur. Hırslanan hatun, şahın huzuruna gidip şehzadeye iftira atar. Bunun üzerine Şah Cefekân, çok sevdiği şehzadesinin boynunun vurulmasını ister. Vezirler şahın bu kararını onaylamazlar. İlk gün birinci vezir gelir ve şahı kararından vazgeçirebilmek için bir hikâye anlatır. Acem şahı kararından vazgeçer. Gece olunca bu sefer hatun bir hikâye anlatır ve şah yeniden oğlunun öldürülmesini ister. Kırk gün boyunca sırası gelen vezir, kadınlara güvenilmemesi temasını işleyen hikâye anlatır. Gece olduğunda ise hatun hikâyelerini anlatır ve şahtan oğlunu ve vezirlerini cezalandırmasını ister. Kırkıncı günden sonra şah oğlunu celladın önüne çıkarıp son kez oğlunun öldürülmesi emrini verdiğinde, şehzadenin üstadı huzura girer ve şaha durumu anlatır. Üstat, oğlana kırk gün boyunca susmasını kendisinin tembihlediğini belirtir. Uğursuzluğun ortadan kalktığını ve şehzadenin artık konuşabileceğini bildirir. Şehzade, hatunun kendisine birliktelik teklif ettiğini ve şah için nasıl bir ölüm planı kurduğunu anlatır. Bu sözlerden sonra şehzade kurtulur. Hatun ise cezalandırılır. Bilgeliği ve hilebazlığı temsil eden karakterlerin savaşını anlatan bu çerçeve hikâyenin içinde, hem vezirlerin hem hatunun anlattığı daha kısa hikâyeler de yer almaktadır. Peygamberler tarihi, tasavvuf, felsefe, edebiyat ve siyaset sahasının tanınmış bazı simalarıyla ilgili daha küçük hikâyeler, bu çerçeve hikâyeye eklemlenmiş biçimde sunulmaktadır.

Kırk Vezir Hikâyeleri, tam bir halk hikâyesi sınıfına sokulamamıştır. Eserdeki hikâyelerin konuları padişahlara, devlet yöneticilerine ve topluma ders vermek amac1 gütmektedir. Bu yönden eser nasihatname ve siyasetname özelliği göstermektedir. ${ }^{2}$ Eserin, Hümayunnâme, Binbir Gece Masallarl ve Kelile ve Dimne'de olduğu gibi, çoğunlukla klasik eğitimden geçmiş çevrelerde okunmak için yazıldığ düşünülmüştür. ${ }^{3}$ Türk edebiyatında Kırk Vezir Hikâyeleri'nin XV. yüzyıldan gelen ilk örnekleri,

1 Hakan Sazyek, Roman Terimleri Sözlüğü Roman Sanatından Yüz Terim (Ankara: Hece Yayınları, 2015), 93-95.

2 Aziz Birinci, "Kırk Vezir Hikâyeleri İnceleme Metin Sözlük” (Doktora tezi, İstanbul Üniversitesi, 2012), 39.

3 Fahir İz, Eski Türk Edebiyatı'nda Nesir XVI ve XIX. Yüzyıl Ortasına Kadar Yazmalardan Seçilmiş Metinler, (İstanbul: Osman Yalçın Matbaası, 1964), 360; Mübeccel Kızıltan, "Kırk Vezir Hikâyeleri”" (Doktora tezi, İstanbul Üniversitesi, 1991), 30. 
Ahmed-i Mısrî tarafından 1446 yılında Arapçadan Türkçeye çevrilerek II. Murad'a takdim edilmiş sonra Şeyhzade tarafından yeniden düzenlenerek hem II. Murad'a hem de Fatih Sultan Mehmed'e sunulmuştur. ${ }^{4}$ E.J.W. Gibb, eserini II. Murad'a takdim eden Şeyhzade hakkında bilgi olmadığını kaydetmektedir. ${ }^{5}$ Kırk Vezir Hikâyeleri'nin kaynağı hakkında değişik görüşler öne sürülmüştür. J. Denny'e göre eserin kaynağı Sinbadnâme' dir. $^{6}$ A. Birinci ise kitabın, varlığ Erbain-i Subh u Mesa isimli Arapça bir eserden çevrildiğini belirtmektedir. ${ }^{7}$ F. Timurtaş ise Erbain-i Subh u Mesa'nın, Kırk Vezir Hikâyesi olarak tanındığını ve Şeyh Ahmed'in eserin konusunu Binbir Gece Masalları'ndan alarak kişisel ilavelerle genişlettiğini öne sürmektedir. ${ }^{8}$ Eserde yer alan çerçeve hikâye, Doğu'da Kitab-ı Sinbâdnâme veya Sinbâdnâme, Batı'da ise Yedi Vezirler veya Yedi Âlimler olarak tanınan eserin konusuyla ${ }^{9}$ benzerlik taşımaktadır.

Kırk Vezir Hikâyeleri'nin Sultan II. Murad ve Sultan II. Mehmed'e sunulmasını takip eden yüzyıllarda da saray içinde okunduğunu gösteren kayıtlar mevcuttur. Osmanlı sarayında müzik hocalığı yapan ve XVII. yüzyıl ortasında görevinden alınan Bobovi, Topkapı Sarayı'nı tanıtan eserinde, iç oğlanlarından bazılarının aralarında Binbir Gece Masalları, Hümayunnâme ve Kırk Vezir Hikâyeleri'nin de bulunduğu kitapları okuduğunu bildirir. Bobovi, bu kitapları "mülemma" adı verilen Türkçe, Arapça ve Farsçanın bir karışımı olan süslü bir dile sahip, zarif ve güzel düşüncelerle dolu eserler olarak nitelemektedir. ${ }^{10}$ Osmanlı saray dilinin üç unsuru olan Arapça, Farsça ve Türkçenin oluşturduğu bu türdeki eserler, saraydaki gençlerin eğitilmesi ve Osmanlı sarayına özgü dil, ahlak, adap ve belli davranış kurallarının kazandırılmasında elverişli ve güzel araçlar olarak görülmüştür. ${ }^{11}$ Kırk Vezir Hikâyeleri'nin iç

4 Mübeccel Kızıltan, "Kırk Vezir," Türkiye Diyanet Vakfi İslam Ansiklopedisi, c. 25 (Ankara: Türkiye Diyanet Vakfi, 2002), 474.

5 Elias John Wilkinson Gibb, The History of Forty Vezirs or The Story of The Forty Morns and Eves, (London: Lowe Brydone, 1886), 8-9.

6 Jean Deny, "Shaikhzade", E. J. Brill's First Encylopedia of Islam 1913-1936, c. 8, (Leiden: E. J. Brill, 1987), 284.

7 Birinci, "Kırk Vezir Hikâyeleri İnceleme Metin Sözlük," 5.

8 Faruk Kadri Timurtaş, "Türkiye Edebiyatı," Türk Dünyası El Kitabı (Ankara, Türk Kültürünü Araştırma Enstitüsü Yayınları, 1976), 430.

9 Sinbadnâme'de bir hükümdarın uzun bir bekleyişin ardından doğan oğlu vardır. Sinbad, bin âlim arasından bu şehzadeyi yetiştirmek için seçilir. Sinbad şehzadenin talihinde yedi gün süren bir uğursuzluk görür ve ona yedi gün konuşmamasını söyler. Çocuğu konuşturmak isteyen bir cariye onu baştan çıkarmaya çalışır. Şehzade onun arzusuna uymayınca, cariye şehzadeye iftira atar. Bunun üzerine şah oğlunun idam edilmesini ister. Şehzadeyi idamdan kurtarmak isteyen şahın yedi vezirinden biri, kadınların hilekâr ve güvenilmez olduklarını söyleyerek şehzadeyi o gün idamdan kurtarır. Ertesi gün cariye, adaletin vaktinde yerine getirilmemesinin yol açtığı sakıncaları anlatarak, şahı yeniden ikna eder. İkinci vezir gelip de hikâyesini anlatınca şah vazgeçer ve yedi gün boyunca vezirlerle cariye hikâyeler anlatırlar. Yedi günün sonunda konuşmaya başlayan şehzade gerçeği söyleyince şah, cariyeyi cezalandırır ve tahtı şehzadeye bırakır. Bkz. Gülşah Gaye Fidan, "Sinbadnâmelerden Hareketle Çerçeve Hikâye Geleneğinde Metinlerarasılık: Tutî Hikâyesi Örneği," Divan Edebiyatı Araştırmaları Dergisi 8, (2012), 68.

10 C. G. Fisher ve A.W. Fisher, "Topkapı Saray1 in the Mid-Seventeenth Century: Bobovi's Decription," Archivum Ottomanicum Anno 10, 1985 [1987]: 78.

11 Emine Fetvac1, Sarayın İmgeleri Osmanlı Sarayının Gözüyle Resimli Tarih, çev. Nurettin Elhüseyni (İstanbul: Yap1 Kredi Yayınları, 2013), 75. 
oğlanlarıyla sınırlı kalmayan bir okuyucu kitlesi vardır. Sultan III. Mehmed'in 1603 yılının Eylül ayında Davud Paşa Sarayı'nda kaldığı sırada okumak için Hazine'den talepte bulunduğu Türkî başlığı altında sınıflandırılmış kitaplar arasında, Kırk Vezir Hikâyeleri de yer almaktadır. ${ }^{12}$ Fakat sultanın isteğinin yazılı olduğu belgede, Kırk Vezir Hikâyeleri' nin musavver olduğuna dair herhangi bir bilgi yer almamaktadır. ${ }^{13}$ Kırk Vezir Hikâyeleri'nin yurt içinde ve yurt dışında birçok yazma nüshası mevcuttur. ${ }^{14}$ Fakat bugüne kadar sadece iki nüshanın minyatürlü olduğu tespit edilmiştir. ${ }^{15}$

\section{Minyatürlü Kırk Vezir Hikâyeleri Nüshaları}

Minyatürlü Kırk Vezir Hikâyeleri nüshalardan biri İstanbul Üniversitesi Kütüphanesi'nde Türkçe Yazmalar Bölümünde T. 7415 numarasıyla kayıtlıdır. Eserin ilk sayfasında (G. 1) en üstte İstanbul Üniversitesi Kitap Sarayı'na ait bir mühür bulunmaktadir.

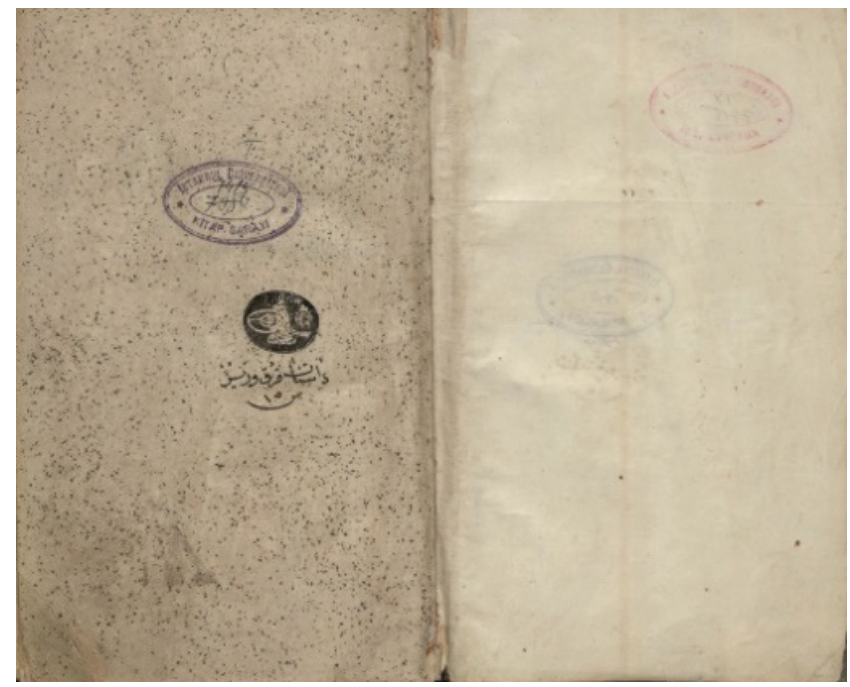

G. 1. Kırk Vezir Hikâyeleri İstanbul nüshası, ilk sayfada yer alan Sultan III. Selim'in mührü, [ï̈, T 7415, 1b]

12 Fetvac1, Sarayın Imgeleri Osmanlı Sarayının Gözüyle Resimli Tarih, 76.

13 Belge Topkapı Sarayı Arșivi E. 861/5. Bkz. İsmail Erünsal, Kütüphanecilikle İlgili Metinler ve Belgeler, (İstanbul: İstanbul Üniversitesi Edebiyat Fakültesi Yayınları, 1982), I: 362-363.

14 Kızıltan, Kırk Vezir Hikâyeleri'nin Türkiye Kütüphanelerinde on üç yurt dıșında ise elli dokuz olmak üzere toplam yetmiş iki nüshasının tespit edildiğini bildirmektedir. Kızıltan, "Kırk Vezir," 474. Ahmed-i Mısrî ve Șeyhzade kolundan gelen bu nüshalar hakkında șimdiye kadar yapılan çalıșmaların bașında Mübeccel Kızıltan'ın doktora tezi oldukça kapsamlıdır. Kızıltan çalışmasında eserin yurt içi ve yurtdışındaki nüshalarını yazar adı, ithaf kaydı, tarih kaydı, kütüphane kaydı ve minyatürlü olup olmaması gibi nitelikler bakımından kataloglamıștır. Bkz. Kızıltan, "Kırk Vezir Hikâyeleri," 307-310. Kırk Vezir Hikâyeleri'nin metni hakkındaki bir diğer çalışma Aziz Birinci'nin doktora tezidir. Tez eserin Topkapı Sarayı Revan Kitaplığı 1081 numaradaki nüshayı incelemesinde esas almıștır. Bkz. Aziz Birinci, "Kırk Vezir Hikâyeleri İnceleme Metin Sözlük” (Doktora tezi, İstanbul Üniversitesi, 2012). Aynı nüsha üzerinde başka bir yüksek lisans tezi de mevcuttur. Bkz. Ayşe Şeker, "Şeyhzade-Kırk Vezir Hikâyeleri, Topkapı, Revan 1081 (vr.1b-35a) İnceleme-Metin-DizinTıpkıbasım," (Yüksek lisans Tezi, İstanbul Üniversitesi, 2013).

15 Kızıltan, "Kırk Vezir," 474. 
İlk sayfada yer alan ikinci mühür Sultan III. Selim’e (1789-1807) aittir. Mührün içinde tuğra formunda "Selim Han bin Mustafa Şah el-muzaffer daima", sağ üst köşesinde ise güzel bir istif ile "Tevekkeltü Alellah" ibareleri, alt kismında ise 1203 (1789) tarihi yer alır. ${ }^{16}$ Sultanın mührünün altında eserin ismi "Dastân-ı Kırk Vezir" olarak kaydedilmiştir. Altında yine siyah mürekkeple bir "s" (sin harfi) ve rakamla 15 ibaresi bulunur. Eser harekeli nesih yazıyla her sayfada 15 satır olacak şekilde yazılmıştır. 9.9 x 5.9 cm ölçülerindeki eserin son sayfasında (G. 2) "hu" ibaresinden sonra "Kanaatte şeref, tamahta zillet vardır" anlamında bir mesel yer alır. Yazma eserin içinde müellif, kâtip ve eserin yazıldı̆̆ı tarih hakkında bilgiye rastlanamamıştır. Eserin, şemse ile süslenmiş deri cildi (G. 3) opak bez ile kaplanmıştır. Hikâyelerin başlıkları ve "Hikayât" ve "Kıssa" ibareleri kırmızı mürekkeple yazılmıştır. Bu nüsha içinde otuz dördüncü vezir hikâye anlatmayıp nasihat vermekle yetindiğinden, vezirlere ait otuz dokuz, hatuna ait kırk hikâye olmak üzere toplamda yetmiş dokuz hikâye yer almaktadır. ${ }^{17}$

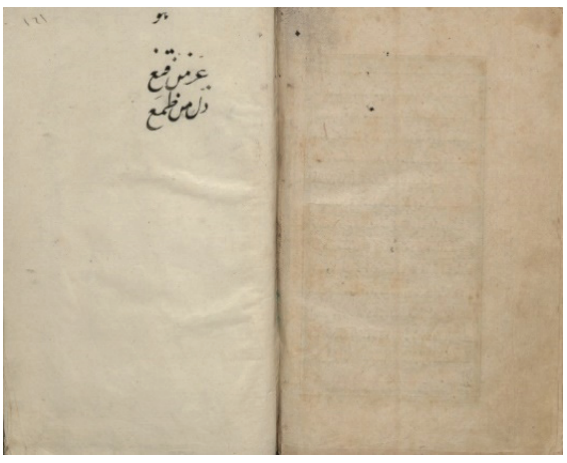

G. 2. Kırk Vezir Hikâyeleri İstanbul nüshas1, [ï̈, T.7415], son sayfa.

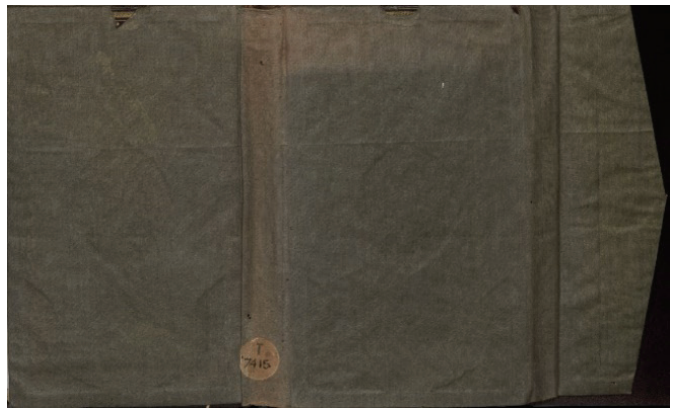

G. 3. Kırk Vezir Hikâyeleri İstanbul nüshas1, [ïÜ, T.7415] cildi.

M. Kızıltan, Kırk Vezir Hikâyeleri'nin yüz altmış varaktan oluşan İstanbul Üniversitesi nüshasının bugüne kadar Türkiye'de tespit edilen tek minyatürlü nüsha olduğunu ve mukaddimesi bulunmayan eserde açık saçık hikâyelere rastlanmadığını bildirir. Bunun muhtemel nedeni olarak da bu nüshanın saray nüshası olabileceğini belirtir. ${ }^{18}$ Yazma eserde on iki minyatür yer almaktadır (1b, 2a, 6a, 9b, 20b, 23a, 40b, 55a, 89b, $124 b, 141 b, 148 a)$.

Eserin mihrabiyeli bir serlevha tezhibi (G. 4) bulunmaktadır. Serlevhadaki dikdörtgen kartuşun içi lacivert zemin üzerinde rumiler, pençler ve yapraklarla bezenmiştir. Kartuşun ortasında beyaz mürekkeple "Haza Kitab-ı Kırk Vezir" yazısı yer almaktadır. Serlevhanın bulunduğu çift sayfada satır araları ve çevresi altınlanmıştır. Eser "Bir gün Sultan Mahmud'un sohbetinde selef padişahlarından birazı zikr olundu... ” cümlesiyle doğrudan Sultan Mahmud ve veziri Ayaz'ın hikâyesiyle başlar.

16 Günay Kut, Yazma Eserlerde Vakıf Mühürleri (Ankara: Kültür ve Turizm Bakanlığı Yayınları, 1984), 42.

17 Kizıltan, "Kırk Vezir Hikâyeleri," 132.

18 Kızıltan, "Kırk Vezir Hikâyeleri,” 132. 


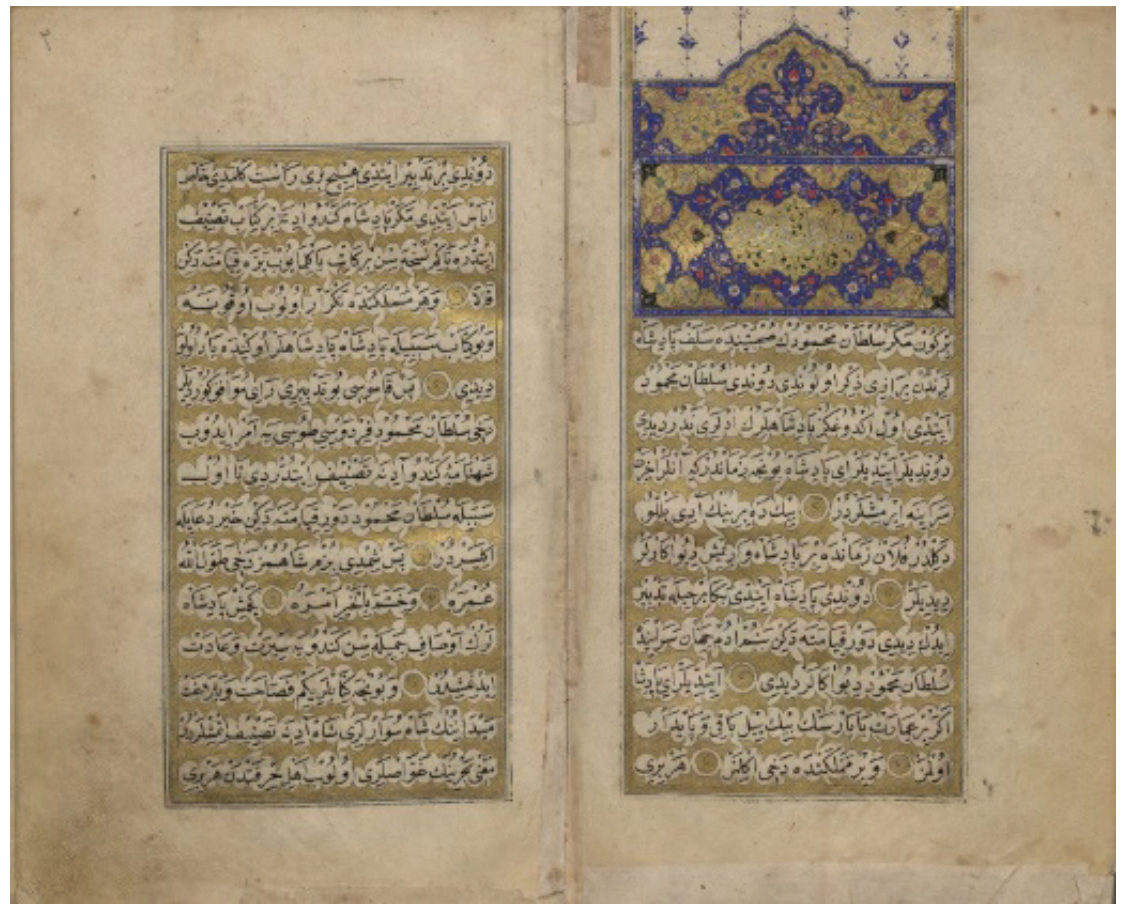

G. 4. Kırk Vezir Hikâyeleri İstanbul nüshası [ï̈, T 7415, 2a] serlevha tezhibi

Kırk Vezir Hikâyeleri'nin ikinci minyatürlü nüshası bugün Uppsala Üniversitesi Carolina Rediviva Kütüphanesi'nin Türkçe Yazmaları arasında Vet. 38 numarada kayıtlıdır. Eserin ismi Kitab-ı Kırk Vezir' dir. Yazma nüsha 22x14 cm ölçülerindedir. ${ }^{19}$ 164 varaklık eser, sayfada 17 satırdan oluşan güzel bir nesih yazıyla kaleme alınmıştır. ${ }^{20} \mathrm{Bu}$ nüsha dil özellikleri ve hikâyelerin içeriği açısından değerlendirilmesine rağmen ${ }^{21}$ eserin minyatürleri üzerinde üslup ve ikonografya açısından herhangi bir çalışma yapılmamıştır. Eserin ilk sayfasındaki (G. 5) mührün içinde "Muhammed Emin ola hakka daim eman" ibaresi eserin sahiplerinden biri hakkında bilgi vermektedir. Mührün son satırında 1155 (1742-1743) tarihi yer almaktadır. Sayfanın üst tarafındaki karalamada "izzetli saadetlü şefaatlü karındaşım" ifadesi ve "Rabbi yes’sir ve lâ tuassir Rabbi" [Rabbim zorlaştırma kolaylaştır. Rabbim.] ibarelerine yer verilmiştir.

$19 \mathrm{https} / /$ www.alvinportal.org/alvin/view.jsf?dswid=7475\&searchType=EXTENDED\&query=+forty+viziers $\& \mathrm{aq}=\% 5 \mathrm{~B} \% 5 \mathrm{~B} \% 7 \mathrm{~B} \% 22 \mathrm{~A}$ FQ $\% 22 \% 3 \mathrm{~A} \% 22+$ forty+viziers $\% 22 \% 7 \mathrm{D} \% 5 \mathrm{D} \% 5 \mathrm{D} \& \mathrm{aqe}=\% 5 \mathrm{~B} \% 5 \mathrm{D} \& \mathrm{af}=\% 5$ B\%5D\&pid=alvin-record\%3314015\&c=1\#alvin-record\%3A14015 Erişim Tarihi 08.02.2019.

20 Carows Johannes Tornberg, Codices Arabici, Persici et Turcici Biblioteca Regiae Universitatis Upsaliensis (Osnabrick: Biblio Verlag, 1988), 63.

21 Kırk Vezir Hikâyeleri'nin Uppsala nüshası, içerdiği hikâyelerin konuları itibariyle Topkapı Sarayı Müzesi Kütüphanesi Revan Kitaplığı 1081 numarada kayıtlı Hicri 1138 [Miladî 1725-26] tarihli minyatürsüz başka bir nüshayla kıyaslanmıştır. Bkz. Ünal Zal, "Kırk Vezir Hikâyelerinin Karşılaştırılması (Uppsala ve İstanbul Metinleri)," Turkish Studies 10/12 (2015): 1275-1318. 


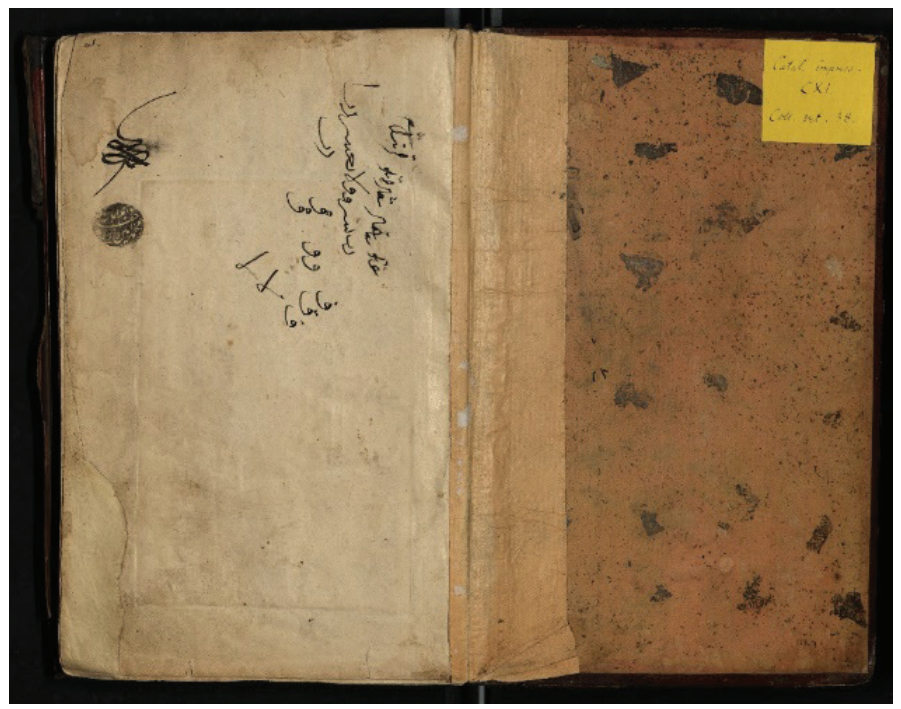

G. 5. Kırk Vezir Hikâyeleri Uppsala nüshasında [UUL Vet. 38,1b] yer alan mülkiyet mührü

Eserin oldukça sade bir cildi (G. 6) vardır. Cildin sırt ve mıklep kısmında yıpranmalar mevcuttur.

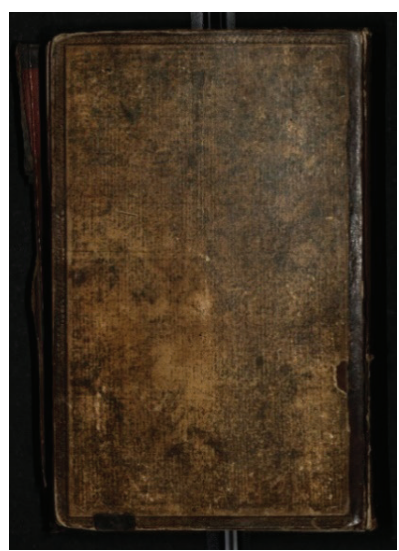

G. 6. Kırk Vezir Hikâyeleri Uppsala nüshas1 [UUL Vet. 38] cildi

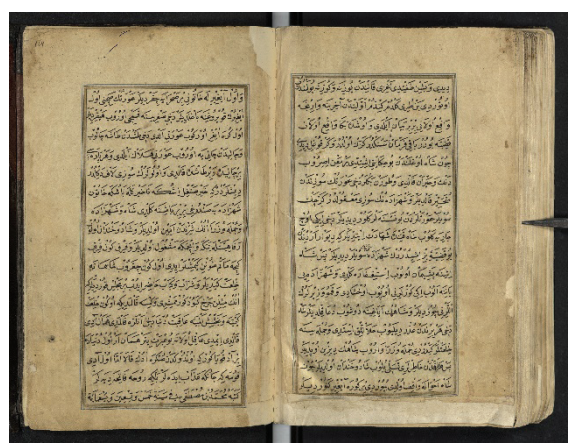

G. 7. Kırk Vezir Hikâyeleri Uppsala Nüshası hatimesi [UUL Vet. 38,164a]

Eserde hatime kaydı (G. 7) bulunmaktadır. 164a'da yer alan kayda göre kâtibin ismi Muhammed bin Mustafa'dır ve eser 1586-1587 (H. 995) yıllarında yazılmıştır. Eserin İstanbul nüshasında olduğu gibi Uppsala nüshasında da müellif hakkında bir bilgi yer almamaktadır. Eser Sultan Mahmud ve Ayaz'ın hikâyesiyle başlamaktadır.

Uppsala nüshasındaki serlevha tezhibi (G. 8), Kırk Vezir Hikâyeleri'nin İstanbul nüshasının serlevha tezhibi (G. 4) ile benzerlik taşımaz. Uppsala nüshasına ait serlevhada kartuşun içinde birleşme noktalarında hatayilerle buluşan sarmal dallar ve 
onların üstünde renk renk pençler, tomurcuklar ve rumiler dikkat çeker. Kartuşun ortasında altın zemin üzerinde beyaz mürekkeple bir besmele yazılmıştır. Yazma eserde 17 minyatür (4b, 6b, 11a, 19a, 22a, 25b, 26a, 35b, 72b, 89b, 98a, 107b, 116a, 134b, 154a, 162b, 163a) bulunmaktadir.

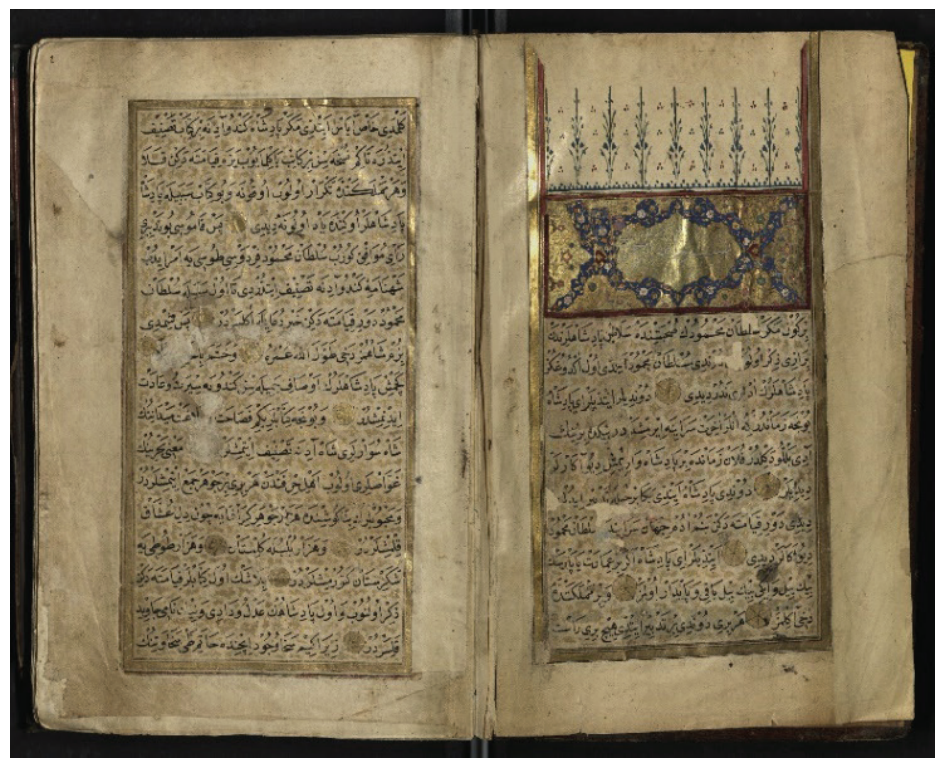

G.8. Kırk Vezir Hikâyeleri Uppsala nüshas1 serlevhas1 [UUL Vet. 38, 1b]

\section{Kırk Vezir Hikâyeleri Minyatürleri Üzerine Bir Karşılaştırma}

Kırk Vezir Hikâyeleri'nin Uppsala nüshasının üzerinde yazan 1586-1587 yılları Osmanlı minyatürünün klasik dönemi içerisindedir. Klasik üslup en verimli çağ1na II. Selim (1566-1574) ve özellikle Sultan III. Murad (1574-1595) döneminde ulaşmıştır. ${ }^{22} \mathrm{Bu}$ dönemin yaratıcısı ise Nakkaş Osman ve ona bağlı çalışan sanatçılardır. Bu sanatçılar bahsi geçen dönemde saray ve çevresindeki seçkinler için birçok minyatürlü yazma eser üretmiştir. Kırk Vezir Hikâyeleri'nin tarihsiz İstanbul nüshasındaki tasvirleriyse, Nakkaş Osman'ın geç dönem çalışmalarından olduğu ve eserin 1580'li yıllar civarında resimlenmiş olabileceği düşünülmüştür. ${ }^{23}$ İstanbul nüshasında çalışan ve Nakkaş A olarak isimlendirdiğimiz sanatçıyla Nakkaş B olarak tabir ettiğimiz Uppsala nüshası sanatçısı arasındaki üslup benzerliği, İstanbul nüshasının Uppsala nüshasına yakın bir tarihte üretilmiş olduğunu göstermektedir. Nüshalar arasındaki benzerlik minyatürlerin üslubuyla sınırlı değildir. Kırk Vezir Hikâyeleri'nin her iki nüshasındaki onar minyatür ikonografik açıdan ortaktır. Ortak olan minyatürler şöyle sıralanabilir:

22 Banu Mahir, Osmanlı Minyatür Sanatı (İstanbul: Kabalcı Yayınevi, 2005), 56.

23 Serpil Bağcı vd., Osmanlı Resim Sanatı (İstanbul: Kültür ve Turizm Bakanlığı, 2006), 204-205. 
1. Şah Cefekân'ın hatununun şehzadeyi kandırmaya çalışması (G. 10/ G. 11)

2. Hatunun Şah Cefakan huzurunda şehzadeyi suçlaması (G. 12/ G. 13)

3. Şeyh Şehabeddin Sühreverd-i Maktül'ün gösterdiği kerametle Mısır şahının hamam önünde beklemesi (G. 14/ G. 15)

4. Şeyh Şehabeddin Sühreverdi'nin katledilmesi (G. 16/ G. 17)

5. Hz. Musa'nın Uc bin Unk'u mucize ile yenmesi (G. 20/ G. 21)

6. Vezirin şahın âşı̆̆ını huzura getirmesi (G. 22/ G. 23)

7. Bir köpeğin yedi bengiden birini yaralaması (G. 28/ G. 29)

8. Çocuğun sözüne uyan Türk obası kadınlarının ağlaşması (G. 24/ G. 25)

9. Emir Semhul ile şahın bir doğanı izlemesi (G. 26/ G. 27)

10. Papağanın bir kadın hakkında hüküm vermesi ve bahçıvanın papağanı satışa çıkarması (G. 31/ G. 32)

Ortak on minyatür dışında eserin Uppsala nüshasındaki diğer minyatürlerin konuları şöyledir: Bir şahın zindandan getirilen üç mahkûmla şehzadelerini sınaması ve büyük şehzadenin hüküm vermesi (G. 18), şahın vezirleri ve bilge kişilerden üç şehzadeden birini veliaht seçmelerini istemesi (G. 19), Şah Cefakan'1n şehzadesini cellat önüne çıkarması (G. 30), Ebu Ali Sina’nın, Konstantiniyye’yi basan fareleri şehrin kapısından çıkarması (G. 33), şehzadenin idamı esnasında şehzadenin hocasının şahın huzuruna gelmesi (G. 34). Eserin İstanbul nüshasında ise ortak on sahne dışında Sultan Mahmud'un meclisi ve sultanın has adamı Ayaz ile sohbetini gösteren çift sayfa takdim minyatürü (G. 9) yer almaktadır.

Kırk Vezir Hikâyeleri'nin İstanbul nüshası çift sayfa takdim sahnesi (G. 9) ile başlar. Takdim minyatüründe bir meclis betimlenmiştir. Sol sayfada bahçe köşkü olarak nitelendirilebilecek bir köşkte taht üzerinde genç bir sultan oturmaktadır. Hemen üstünde yer alan Sultan Mahmud ibaresi hem sultanın kimliğini hem de meclisin sahibini işaret etmektedir. Kırk Vezir Hikâyeleri'nin minyatürlü iki nüshası da doğrudan Sultan Mahmud'un (Gazneli Mahmud'un) ${ }^{24}$ meclisinden bir hikâyeyle başlamaktadır. Fakat bu hikâye eserin sadece İstanbul nüshasında resmedilmiştir. Hikâyeye göre sultan, huzurunda bulunanlardan isminin kıyamete kadar cihanda Sultan Mahmud olarak anılmasını sağlayacak bir iş tavsiye etmelerini ister. Haslarından Ayaz, sultana bir kitap tasnif ettirmesini salık verir. Sultan Mahmud bu tavsiyeden sonra Firdevsî Tusi'ye Şahnâme' yi kendi adına tasnif etmesini emreder. Bu sebeple Sultan Mahmud devri kıyamete değin hayır duayla anılır. ${ }^{25}$ Minyatürde (G. 9) Sultan Mahmud'un has adamlarıyla bu meseleyi tartışma anı betimlenmiştir.

24 Gazneli Hükümdarı Sebüktekin'in oğlu olan Sultan Mahmud Türk-İslam devletlerinin önde gelen hükümdarlarından biridir. Hint ile İslam dünyası arasındaki kültür ve ticaretin gelişmesini sağlayan hükümdar, âlimlere olan saygısı ve adaletli yönetimi nedeniyle devrin şairleri tarafından övülen biridir. Firdevsî, Şahnâme'sini Gazneli Mahmud'a sunmuştur. Bkz. Erdoğan Merçil, "Mahmûd-1 Gaznevî," Türkiye Diyanet Vakfi İslam Ansiklopedisi, c. 27 (Ankara: Türkiye Diyanet Vakfı, 2003), 362-365.

25 Kırk Vezir Hikâyeleri, İstanbul Üniversitesi Kütüphanesi T. 7415, 3a-3b. 


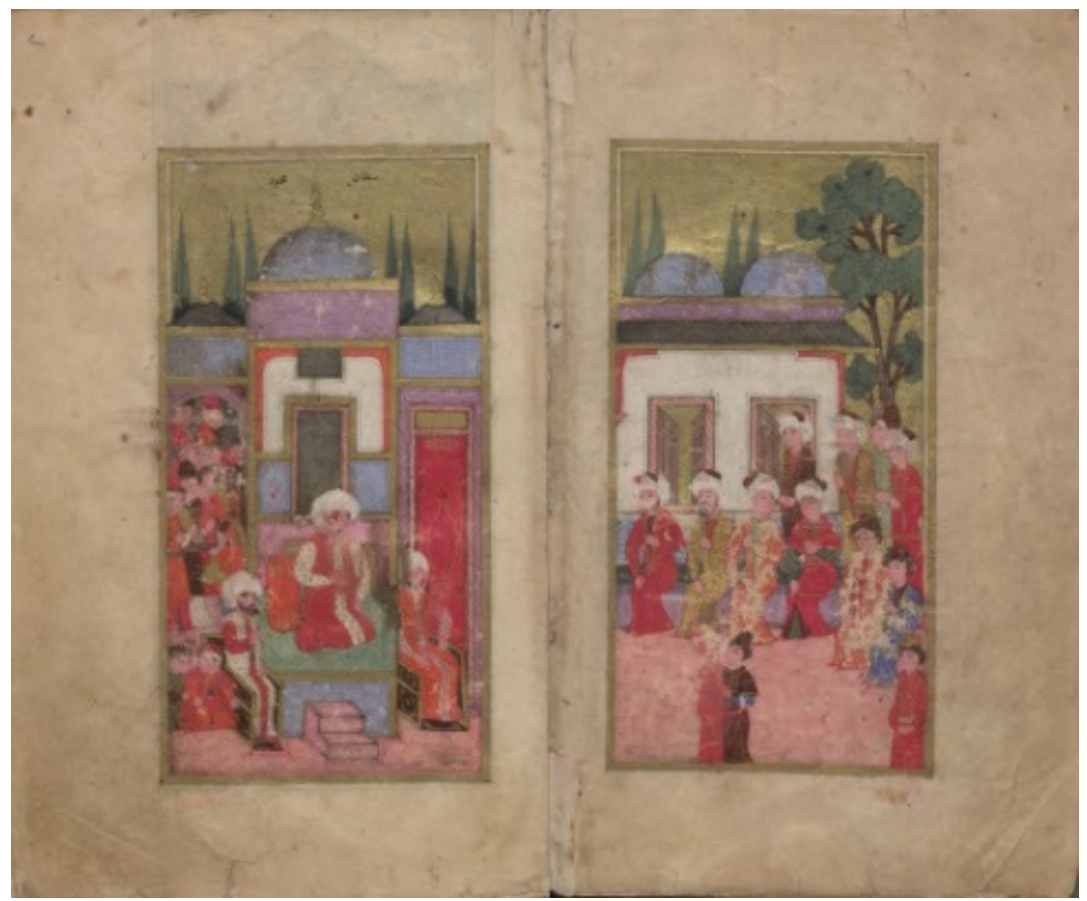

G. 9. Sultan Mahmud'un meclisi ve sultanın has adamı Ayaz ile sohbeti, Kırk Vezir Hikâyeleri, [ï̈̈, T. 7415, 1b-2a]

Tasvirde Sultan Mahmud'un karşısında dizilmiş figürler içinde, yüzü sultana dönük olan genç erkek, Ayaz olmalıdır. O da sultanın diğer akil adamları gibi bir sedir üzerinde oturmaktadır. Tek elini konuşma işareti olarak kaldırmıştır. Ayaz ${ }^{26}$ Mevlana'nın Mesnevi'sinde padişah (Gazneli Mahmud) hazinesinin en has kulu, hatta padişahın canı olarak anılır. ${ }^{27}$ İ. Kafesoğlu, Ayaz'ın Sultan Mahmud'un gulamlarından olduğunu ve sultana sakilik yaptığını, sultanın diğer meşhur gulamları ve devlet erkânıyla birlikte, şair ve ediplere eserlerini duyurmak firsatı verilen meclislerde hazır bulunduğu bilgisini vermektedir. ${ }^{28}$ Sultan Mahmud'un ve Ayaz'ın isimleri, yaşadığı dönemden sonraki çağlara da taşınmıştır. Bu minyatür, hem bilge kişilere danışan bir sultan imgesinin, hem de akıl ve feraset sahibi, sultana sadık örnek bir has adam imgesinin yüceltilmesi olarak yorumlanmalıdır. Diğer taraftan bu sahne Şahnâme'nin macerasının başladığı anı da tasvir etmektedir. İslam resminde, Sultan Mahmud'u, Firdevsî

26 Ahmet Talat Onay kaynağını belirtmeden Ayaz’a ilişkin bilgiler vermektedir. Onay’a göre Ayaz, Sultan Mahmud devrinden sonra Sultan Mesud devrinde ordu kumandanı olarak şehirler zapt etmiş ve Hicri 449'da (1057-1058) ölmüştür. Gazneli Mahmud'un has gulamlarından biridir. Akıl, feraset, bilgi ve sadakat vasıflarına sahip olduğu için sultan tarafından çok sevilmektedir. Bkz. Ahmet Talat Onay, Eski Türk Edebiyatında Mazmunlar ve İzahı, haz. Cemal Kurnaz (Ankara: Türkiye Diyanet Vakfi, 1993), 279-280.

27 Muhammed b. Muhammed b. Hüseyin Mevlânâ Celaleddin-i Rumî, Mesnevi Tercümesi ve Şerhi, tercüme ve şerh Abdülbaki Gölpınarlı (İstanbul: İnkılap ve Aka Kitabevleri, 1984), V-VI: 1871.

28 İbrahim Kafesoğlu, "Mahmud Gaznevî," İslam Ansiklopedisi: İslam Alemi Tarih, Coğrafya, Etnografya ve Biyografya Lugatı, c. 5/1 ( İstanbul: Milli Eğitim Bakanlığı, 1987), 182. 
ve Gazneli şairleri huzurunda toplamış bir sultan olarak gösteren sahneler mevcuttur. Ayaz ise Şehnâme resimlerinde, Sultan Mahmud'un Firdevsî'ye telif ücretini getiren saray görevlisi olarak betimlenmiştir. ${ }^{29}$ Fakat Kırk Vezir Hikâyeleri minyatüründe Ayaz, sultan ve maiyeti arasında aracılık yapan sıradan bir saray görevlisi değil, bir vezir gibi sultana akıl ve tavsiye veren bir imge içindedir.

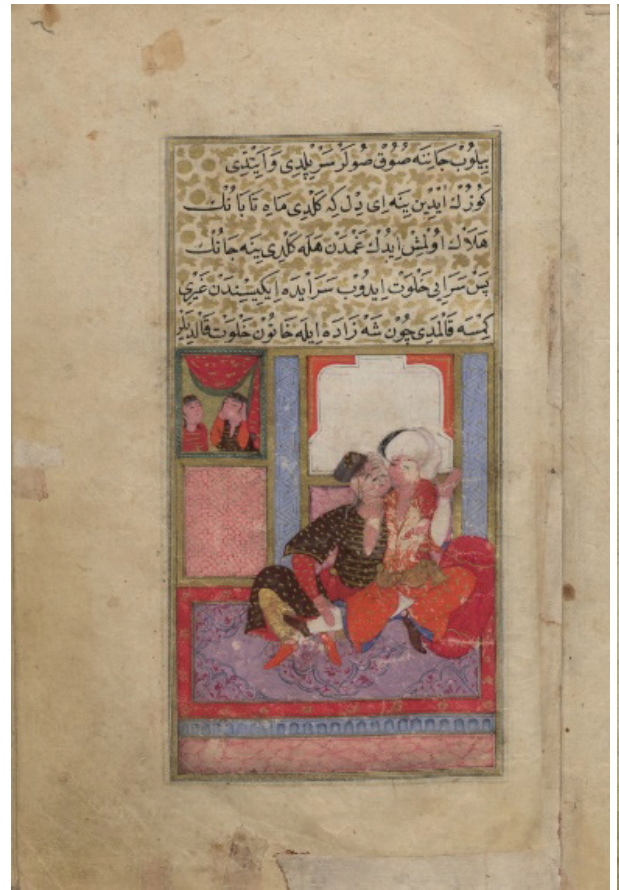

G. 10. Şah Cefekân'ın hatununun şehzadeyi kandırmaya çalışması, [ïÜ, T. 7415, 6a]

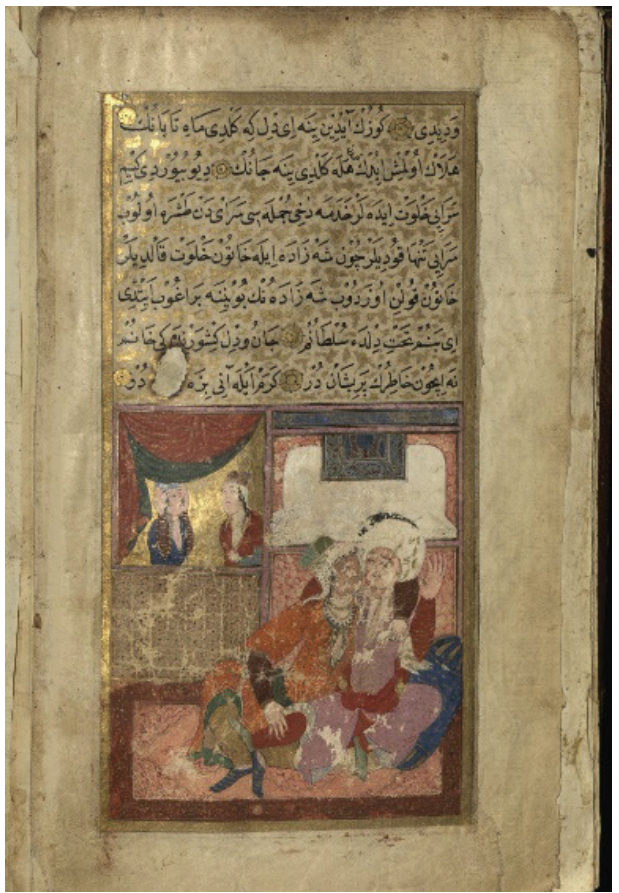

G.11. Şah Cefekân'ın hatununun şehzadeyi şehzadeyi kandırmaya çalışması, 1586-1587, [UUL Vet. 38, 4b]

Kırk Vezir Hikâyeleri'nin İstanbul nüshasının ikinci (G. 10), Uppsala nüshasının ise ilk minyatürünün (G. 11) konusu eserin çerçeve hikâyesine aittir. Minyatürlerde Şah Cefekân'ın karısının, şahın eski eşinden olan güzel yüzlü şehzadesine gayrimeşru ilişki teklif etme ${ }^{30}$ anı tasvir edilmiştir. Her iki tasvirde de kurgu aynıdır.

29 Zeren Tanınd, "Sultanlar, Şairler ve İmgeler; Şehnâme-i Firdevsî’nin Mukaddimesi’nin Resimleri," İstanbul Üniversitesi Sosyal Bilimler Dergisi 15 ((2008/2), 279.

30 Hikâyeye göre şehzade konuşmayınca padişah lalasına oğlunun hüzün ve kederi olduğunu, onu (üvey) annesine yollamalarını, annesinin onu konuşturabileceğini söyler. Lala şehzadeyi hatunun katına götür. Hatun fırsatı ganimet bilir. Sarayda ikisinden başka kimse kalmadığında, hatun kolunu şehzadenin boynuna dolayıp şehzadeye babasının her ne malı varsa kendisinin olduğunu ve eğer şehzade işbirliği yapar ve "gömlekten baş çıkarır" ise kendisinin onun gamını giderebileceğini söyler. Babasının kocamış bir adam olduğunu, kendisinin ise genç bir hatun olduğunu da vurgular. Eğer şehzade onunla gönül birliği ederse padişahı helak edip şehzadeyi padişah kılabileceğini ekler. Şehzade hiç cevap vermez. Hatun başkaca sorular sorar. Şehzade yine cevap vermeyince hatun kolu şehzadenin boynunda olduğu halde, şehzadeyi kuşağından çekip bağrına bastırıp bir buse almak ister. Şehzade elinin arkasıyla hatunun ağzına bir tokat atar ve kadının ağzı kan dolar. Kırk Vezir Hikâyeleri, T. 7415, 5b-7b. 
Minyatürlerde üvey anne genç şehzadeye sokulmuş vaziyette oturmaktadır. Tek kolu şehzadenin omzundadır. Üzerindeki elbisenin göğüs kısmı açıktır. Eliyle şehzadenin bacağını tutmaktadır. Şehzadenin tek eli havadadır. Hikâyede bahsedildiği üzere üvey annesinin kösnül isteklerini reddetmiş ve elini üvey annesine tokat atmak için kaldırmıştır. Nakkaşlar metinle birebir uyumlu olacak şekilde hikâyenin en can alıcı noktasını tasvir etmeyi seçmiştir. Hatun’un şehzadeyi kötü yola sürüklemek için gösterdiği çabayı, pencereden sarayın iki kadın hizmetçisi şaşkınlıkla izlemektedir. Minyatürleri (G. 10, G. 11) çevreleyen hikâyede, üvey annenin şehzadeye yaklaştığ1 anı gören kimsenin varlığından bahsedilmez. Fakat eserin sonunda, şehzadenin suçsuzluğunu kanıtlamak için üç cariye şaha gelir. Cariyeler, şehzadenin doğru söylediğini, (hatunun emellerini) duvar ardından işittiklerini şaha bildirirler. ${ }^{31}$ Eserin sonunda yer alan kilit mahiyetindeki bu detayın Nakkaş A ve Nakkaş B tarafından ilk resimde gösterilmesi, nakkaşların sadece anekdota değil, kitabın tümüne hâkim olduklarını ve minyatürlerde ilişkiselliği gözeten bir planla hareket ettiklerini düşündürür.

Kırk Vezir Hikâyeleri'nin her iki nüshasında yine çerçeve hikâyeye ait birer minyatür (G. 12, G. 13) istekleri geri çevrilen hatunun, şahın huzurunda şehzadeyi kendisine saldırmakla suçlamasını konu edinmektedir. ${ }^{32}$ İstanbul nüshası minyatüründe (G. 12) şah, üstü kubbeyle örtülü bir bahçe köşkünde tahtta oturmaktadır. Sorguçlu iri kavuğu ve elindeki mendil, sultanî asaletini tamamlayan unsurlardır. Karşısında diz çökmüş hatunun siyah uzun saçları çözülmüştür. Hatun başındaki örtüyü ve başlığı çıkarmak üzeredir. Desenli beyaz elbisesinin yakası neredeyse göbeğine kadar açıktır. Şehzadenin kendisine el uzattı̆̆ını ispat etmek isteyen hatunun perişan hâli Nakkaş A tarafından ustaca işlenmiştir. Aynı ikonografiyi paylaşan Uppsala minyatürü (G. 13) sahnenin kurgulanışı ve resimdeki unsurlar açısından da Nakkaş A'nın tasvirine (G. 12) çok benzemektedir. Fakat Nakkaş B (G. 13) sahneye köşk duvarının berisinde birbirleriyle konuşan iki saray görevlisi kadını da dâhil etmiştir.

31 Klrk Vezir Hikâyeleri, T. 7415, 159 b.

32 Hatun başını açıp, saçlarını sağa sola dağıtıp, ağız kanından kaşlarının yanlarına ve yanağına bulaştırır. Şehzade odasına gider ve ilimle meşgul olur. Bir süre sonra padişah gelir ve şehzadenin gönlünü almak ister. Fakat hatununu kızıl kanlara bulanmış, başını çözmüş ve saçları perişan ve hüzünlü halde oturur bulur. Kadın padişaha şehzadenin onu bu hâle getirdiğini, onun gam ve kederini gidermek istediğini, fakat şehzadenin ona el uzattığını söyler. Onu men ettiği hâlde şehzadenin ona "Eğer sen benimle ahd edip gönül verirsen, atamı öldürüp seni bana helal ederim" dediğini iddia eder. Şehzadenin kendisinin dürüstlüğünü anlayınca onu öldürmeye kast ettiğini, kendisinin feryat ettiğini ve şehzadenin çıkıp gittiğini söyler. Kırk Vezir Hikâyeleri, T. 7415, 8a-9a. 


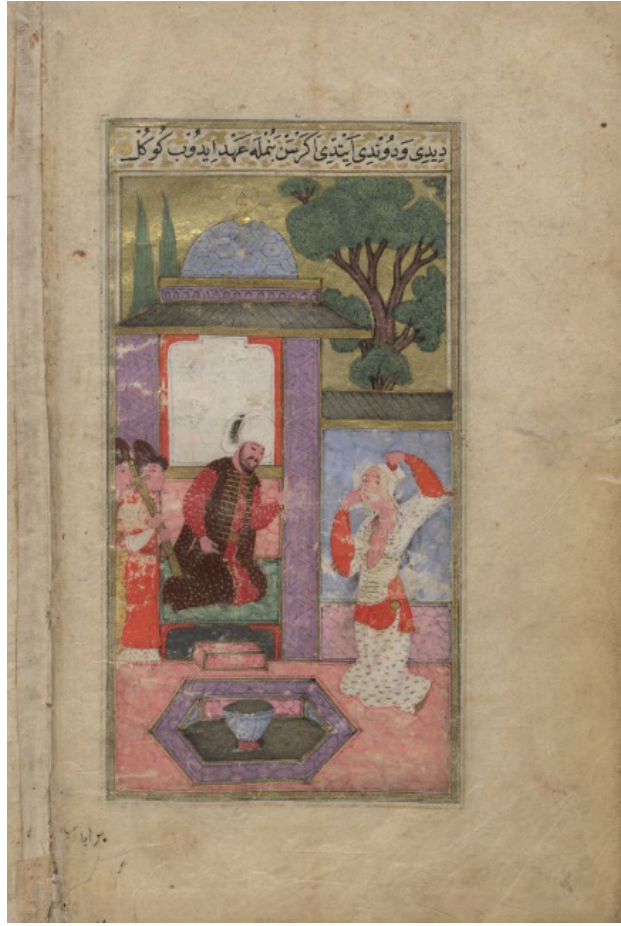

G. 12. Hatunun Şah Cefakan'nın huzurunda şehzadeyi suçlaması [İ̈̈, T. 7415, 8b]

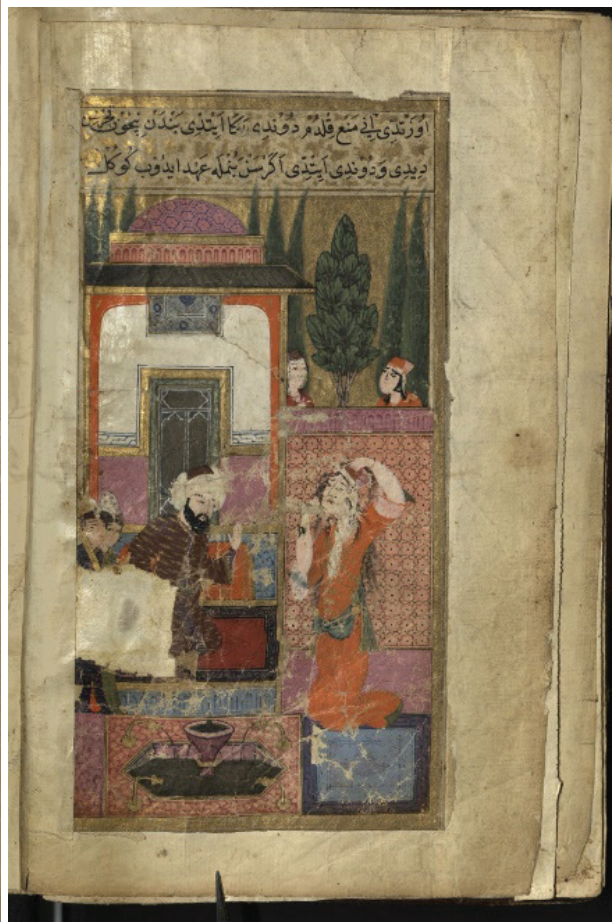

G. 13. Hatunun Şah Cefakan'nın huzurunda, şehzadeyi suçlaması, 1586-1587, [UUL Vet. 38, 6b].

Kırk Vezir Hikâyeleri'nin her iki nüshasında ortak ikonografiye ait diğger iki sahne$\operatorname{nin}($ G. 14, G. 15) konusu, çerçeve hikâyeye eklemlenmiş bir iç hikâye aittir. Bu, birinci vezirin, şehzadesinin hükümdarlık tahtında ve karısında gözü olduğunu düşünen Şah Cefekân'1 fikrinden vazgeçirmek ve şehzadeyi idamdan kurtarmak için anlattığ hikâyedir. Hikâyede Şehabeddin-i Maktül'ün ${ }^{33}$ ziyaret ettiği bir adamın başından geçenler konu edilmiştir. Hikâyeye göre Mısır şahı, Hz. Muhammed'in Mirac hadisesiyle ilgili dönemin bilginlerinin anlattığı rivayetlere inanmaz. Bu rivayetler, peygamberin her birinin arası beş yüzyıllık bir mesafe olduğuna inanılan yedi kat gögü geçip, sonra cennet ve cehennemi gördüğünü daha sonra Allah ile doksan bin kelam edip döndüğünde yatağının bile soğumamış olduğundan bahsetmektedir. Mısır şahının bu inkârı Şeyh Şehabeddin-i Maktül'ün kulağına gider. Şeyh, şahı ziyaret etmeye karar verir. Şeyh, oturdukları odanın penceresinden sultana bazı olağanüstülükler gösterir.

33 Şeyh Şehabeddin Maktül İslam felsefesinin öne çıkan isimlerindendir. İslam kültüründe Ebu’l Şehabeddin Yahya b. Habeş b. Emirek es-Sühreverdi el-Maktûl (ö. 587/1191) olarak bilinmektedir. İşraki felsefe akımının kurucusu sayılan bu filozofun Diyarbekir çevresinde ve Anadolu'nun başka topraklarında seyahat ettiği ve Artuklu Harput Emiri için bir kitap telif ettiği bilinmektedir. Kitaplarında semboller kullanarak mistik fikirler sunan bu filozof İslam düşünce tarihi içinde felsefi-mistik geleneği inşa eden kişi olarak kabul edilmektedir. Bkz. İlhan Kuluer, "Sühreverdî Maktül," Türkiye Diyanet Vakfi İslam Ansiklopedisi, c. 38, (İstanbul: Türkiye Diyanet Vakfi, 2010), 36-40. 
Sonra onu bir leğen içerisinde suya daldırıp dağ dibindeki bir denizin kenarına yollar. Şeyhin onu ilimle yabana saldığını anlayan şah, gördüğü oduncularla birlikte şehre gider. Bir nalbant dükkânında bir pirin oturduğunu görür. Ona kendisinin bir bezirgân olduğunu ve gemisinin battığını söyler. Pir ona hamam kapısında oturmasını, çıkan kadınlara kocası olup olmadığını sormasını ve yok diyen olursa o kadınla evleneceğini çünkü burada nikâhlanmanın bu şekilde olduğunu söyler. Kadının mal varlığıyla bir zaman geçinebileceklerini de bildirir. ${ }^{34}$

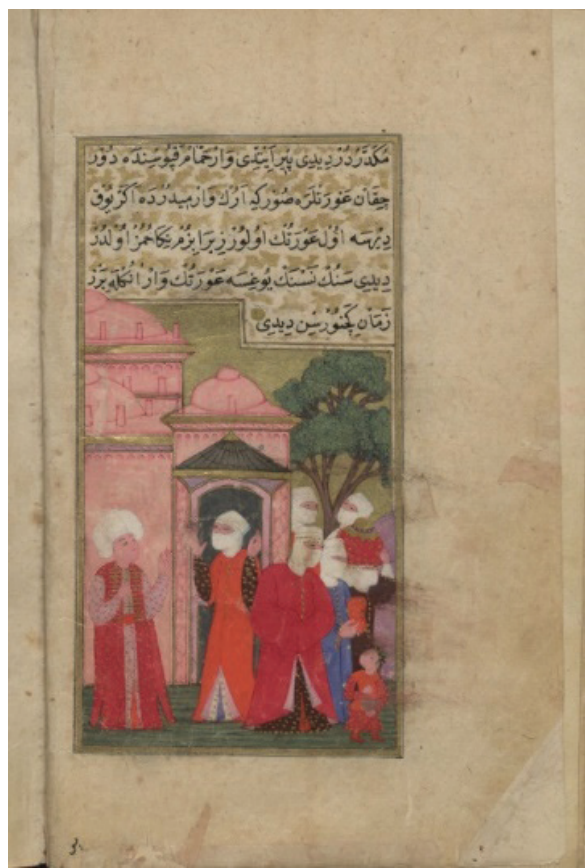

G.14. Şeyh Şehabeddin-i Maktül'ün gösterdiği kerametle Mısır şahının hamam önünde beklemesi

[İ̈̈ T. 7415, 20b], [Bağc1 vd., 2006, G.166]

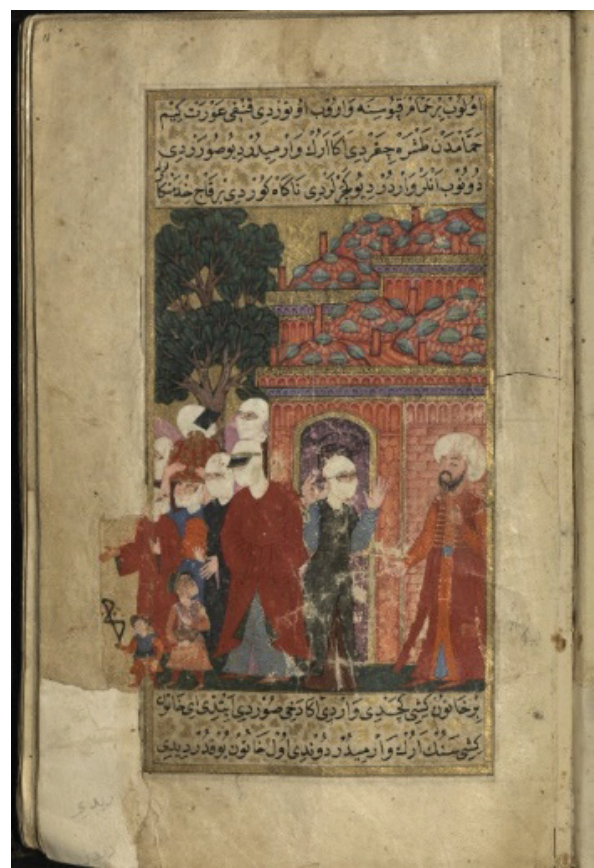

G.15. Şeyh Şehabeddin-i Maktül'ün gösterdiği kerametle Mısır şahının hamam önünde beklemesi 1586-1587, [UUL Vet. 38, 11a].

Minyatürlerde (G. 14, G. 15) Mısır sultanı bir hamam önünde evleneceği kadını beklerken tasvir edilmiştir. Eserin İstanbul nüshası minyatüründe (G. 14) sultan, yüzünde tüy olmayan genç bir erkek olarak betimlenmiştir. Sultanla konuşan kadının kıyafetleri hamamdan çıkan diğerleriyle aynıdır. Beyaz örtü ve yaşmağın altında sadece gözleri görünmektedir. Nakkaş A, bir grup halinde sokağa yönelmiş bu kadınları hamam bohçaları ve çocuklarıyla beraber gündelik hayat içinden bir sahneye yerleştirmiştir. Eserin Uppsala nüshasında aynı ikonografiyi gösteren minyatür (G. 15) hem figürlerin sahneye yerleştirilmesi hem de mimari unsurlar açısından diğer resimle büyük benzerlik taşımaktadır. Fakat burada sultan orta yaşlı bir adam gibidir. Nakkaş B hamam mimarisini özenle betimlemiştir.

34 Kırk Vezir Hikâyeleri, T. 7415, 17b-20b. 
Misır sultanı, şeyhin isteği üzerine bir leğendeki suyun içine dalmış ve kendisini bambaşka bir âlemde bulmuştur. Olağanüstü bir yolla sarayına döndüğünde ise yedi yıl boyunca sarayından ayrı kaldığını ifade eder. Fakat şeyh, yedi yıl olarak yaşadığı vaktin gerçekte leğendeki suya dalma anı kadar kısa olduğunu anlatır ve sultanın adamları da bunu doğrular. ${ }^{35}$ Hikâyeye göre Misır sultanın bu olağanüstü yolculuğunu mümkün kılan Şeyh Sühreverdî’nin hikmetidir. Tasavvuf literatüründe bir sufiden ortaya çıkan olağanüstü hâller keramet olarak nitelendirilmektedir. ${ }^{36} \mathrm{Bu}$ iki minyatür, keramet ikonografyasına dâhildir.

Mısır sultanı tahtından ayrı kaldığı için şeyhe kızgındır ve vezirlerinden aldığı akılla Şeyh Şehabeddin'i öldürtmeye karar verir. Vezirlerin planı güzel bir kadınla şeyhi tuzağa düşürüp öldürtmektir. Eserin her iki nüshasındaki birer minyatürde Sühreverdî’nin öldürülme anı (G. 16, G. 17) betimlenmiştir. Her iki minyatürün kurgusu birebir aynıdır. Cariye, şeyhe bu hikmetin ne zaman ortadan kalktığını sorunca, şeyh cenabet hâldeyken bu hikmetin kalktığını söyler. Cariye, beylerine gece hazır olmalarını, şeyhle yakınlık kurduğunda gelmelerini söyler ve şeyhin gusül etmek için hep hazırda tuttuğu iki testi suyu da döker. İkisi birlikte olduktan sonra şeyh gusül etmek istediğinde, cariye su olmadığını bahane ederek dışarı çıkar ve askerlere haber eder. Şeyh onları görünce durumu anlar ve şamdandan iki mum alıp dönmeye başlar. Kılıçla şeyhi şehit ederler. ${ }^{37}$

Her iki nakkaş da yukarıda anlatılan hikâyeyle birebir uyumlu olacak şekilde bir sahne (G. 16, G. 17) sunmaktadır. Vaktin gece olduğu pencereden görünen ay ve yıldızlarla belirtilmiştir. Şeyhin gusül abdesti için hazır ettiği testi resmin ön planında boş şamdanların yanında durmaktadır. Şeyh giyiniktir fakat ayakları çıplaktır. Elinde iki mum taşıyan şeyhin bakışları katillerine yönelmiştir. Mısır sultanının üç adamı, şeyhe saldırmaya hazırlanmaktadır. Adamların arkasında şeyhe oyun oynayan hilebaz cariye bekler. Hikâyenin ana öğüdü, hikmet sahibi bir şeyhin bile zaaf gösterdiği anda kadın hilesinden kurtulamayacağıdır. Zaten vezirlerin anlattığı hikâyelerde kadınlar genellikle hilekâr olarak yansitılmaktadır.

35 Kırk Vezir Hikâyeleri, T. 7415, 21 b.

36 Keramet, peygamberlik iddiası taşımaksızın bir kişide harikulade bir halin ortaya çıkmasıdır. Keramet, Hakk'ın velisine bir ikramı olarak kabul edilmiştir. Süleyman Uludağ, Tasavvuf Terimleri Sözlüğü (İstanbul: Kabalcı Yayıncılık 2012), 211.

37 Kırk Vezir Hikâyeleri, T. 7415, 22b-23a. 


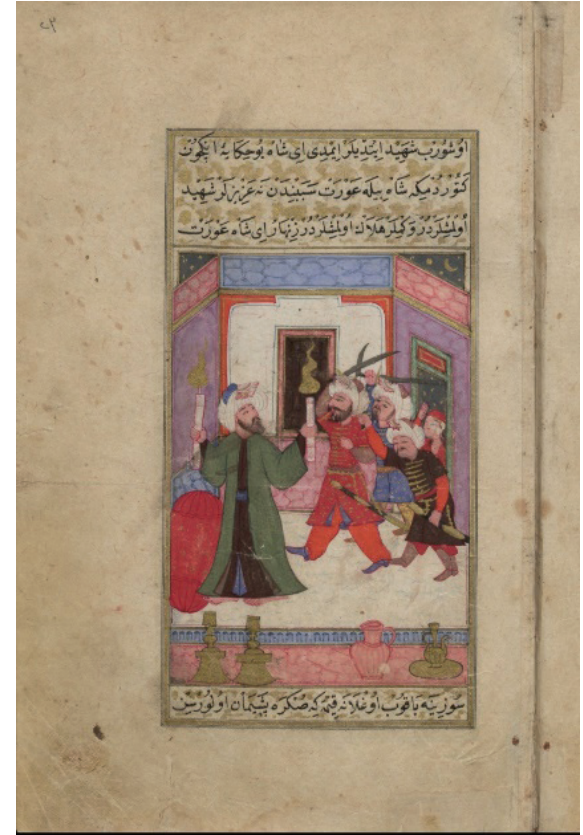

G. 16. Şeyh Şehabeddin-i Maktül'ün katledilmesi

[Ï̈̈ T. 7415, 23a], [Bağc1 vd., 2006, G.167]

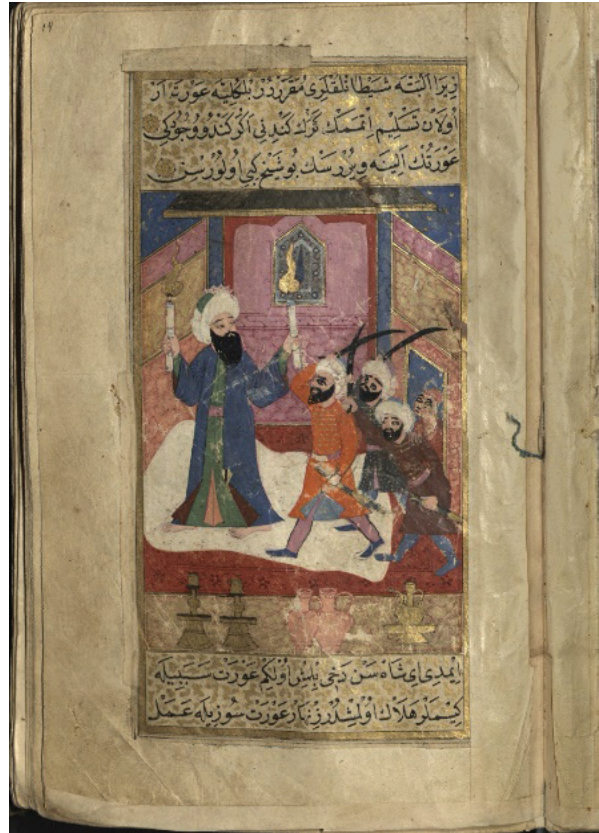

G. 17. Şeyh Şehabeddin-i Maktül'ün katledilmesi

1586-1587, [UUL Vet. 38, 19a].

Şeyh Sühreverdî-i Maktül'ün ölüm anını gösteren bu sahneler, İslam sanatı açısindan eşsizdir. İslam tarihinde Sühreverdî-i Maktül'ün ölüm sebebine dair yaklaşımlar farkl1lık göstermektedir. İ. Kutluer, Sühreverd̂̂’nin görüşlerinin, Selahaddin-i Eyüb'ün oğlu el-Melikü'üz-Zahir'in Halep'teki sarayına kadar nüfuz etmesinin, medrese hocaları tarafından tehlikeli addedildiğini ve hayatının talihsiz bir biçimde son bulduğunu belirtmektedir. Ölüm şekli hakkında, bir sicimle boğulduğu, kılıçla idam edildiği, kaleden atılarak öldürüldüğ̈̈ ve cesedinin yakıldığ1 gibi çeşitli rivayetler vardır. ${ }^{38}$ Kırk Vezir Hikâyeleri ise Şeyh Sühreverdî-i Maktül'ün ölümüne bambaşka bir açıdan yaklaşmış ve ölüm sebebini, hoşlandığı ve güvendiği bir cariyenin hilesi olarak sunmuştur.

Kırk Vezir Hikâyeleri'nin Uppsala nüshası minyatürleri, sayıca İstanbul nüshası minyatürlerinden fazladır. Tahta layık bir idarecinin sahip olması gereken adalet ve fazilet gibi temel özelliklerden bahseden bir iç hikâyeyi görselleştiren üç minyatür sadece Uppsala nüshasında yer almaktadır. Bu iç hikâyede yüz yirmi yıl cihanda hükmetmiş ve artık tahtı üç oğlundan birine bırakmak isteyen bir şahın hikâyesi anlatılmaktadır. Hikâyeye göre ilk gün tahta büyük oğlan geçer. Büyük görevleri akil

38 İlhan Kutluer, "Sühreverdî Maktül," Türkiye Diyanet Vakfi İslam Ansiklopedisi, c. 38 ( İstanbul: Türkiye Diyanet Vakfi, 2010), 36-40. 
ve âlim kişilere verip onları katında toplar ve cahil kişileri yanından uzaklaştırır. Şah oğlunun hükmünü tecrübe etmek için zindandan üç kişi çıkarır. Bunlardan biri kan dökmüş, biri kıyafet çalmış (esbab ugurlamış) ve biri de zina etmiştir. Bu kişilerin davaları görülmeye başlar. Şehzade onların meselelerini anlar, ata ve analarının emek verdiği bu kişileri öldürmek istemez, onlardan tövbe etmelerini ister ve onları serbest bırakır. "Bunları yok etmek reva değildir," der ve onlara tövbe ettirir. Hükmettiği üç günden halk çok memnun olmuştur. Dördüncü gün olduğunda nöbet, ortanca oğlana geçer. ${ }^{39}$ Minyatürde (G. 18) bu üç şehzadeden büyük olanın tahta geçip, yönetme işini tecrübe etmesi tasvir edilmiştir.

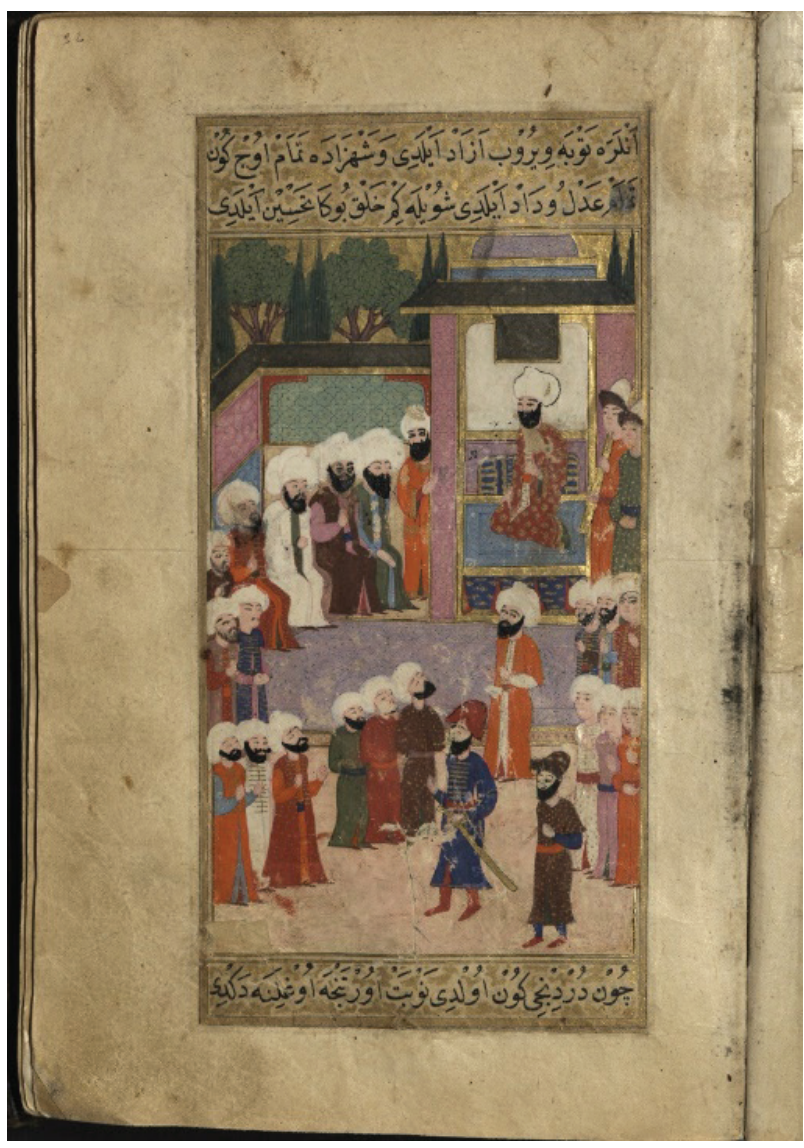

G. 18. Bir şahın zindandan getirilen üç mâhkumla şehzadelerini sınaması ve büyük şehzadenin hüküm vermesi, Kırk Vezir Hikâyeleri, 1586-1587, [UUL Vet. 38, 22a]

Minyatürde (G. 18) bahçe köşküne kurulmuş taht üzerinde şahın en büyük şehzadesi oturmaktadır. Şehzadenin üç suçluyu mahkeme etmesi betimlenmiştir. Sol tarafta sedirde oturanlar şehzadenin seçtiği âlimlerdir. Üç suçlu ortada elleri arkalarından bağlanmış şekilde durmaktadır. Tahtla suçlular arasındaki genç adam davacılardan 
biri olmalıdır. Kırmızı başlıklı ve belinde kılıç taşıyan saray görevlisi asayişi sağlamak üzere tam ortada durmaktadır. Minyatür, saltanat sisteminde doğuştan yönetme hakkına sahip şehzadeler arasında adaletle hükmetmeye en uygun olan adayın belirlenebilmesi amacındaki bir yöntemin görselleştirilmesidir.

Eserin Uppsala nüshasında şah ve üç şehzadesiyle ilgili hikâyenin tasvir edildiği çift sayfa minyatür (G. 19) ise şahın vezirleriyle birlikte kendisinden sonra şah olacak şehzadeyi tayin etme toplantısının tasviridir. Sağ sayfada şah bir bahçe köşkünde oturmaktadır. Üç şehzade tahtın ayağına serilmiş halının hemen önündedir. Kısa kollu kaftanlar giymiş hâlde betimlenen genç şehzadeler sahnenin ortasında şaşkın vaziyette durmaktadırlar. Hikâye metninde şahın bilge adamlarını sahrada topladığı belirtildiğinden, Nakkaş B bilge kişileri sol sayfada çimenler üstünde tartışırken resmetmiştir. Bilgeler şahın küçük oğlunun âlim ve akıllı olduğunu ve yönetmeye daha uygun olduğunu bildirmiş, şah da sarayına döndüğünde onu tahta çıkarmıştır. ${ }^{40}$

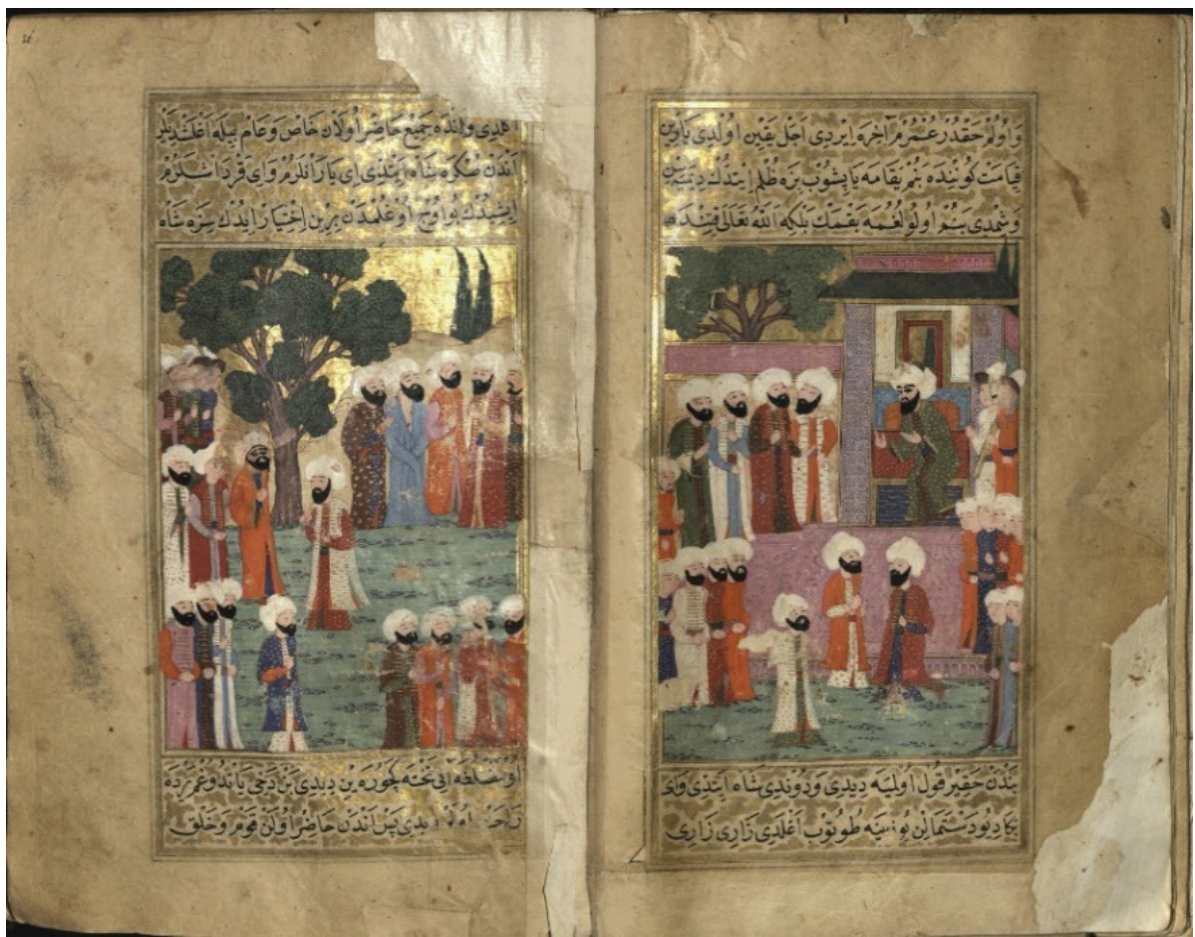

G. 19. Şahın veliaht tayininde vezirleri ve bilge kişilerden üç şehzadeden birini seçmelerini istemesi, 1586-1587, [UUL Vet. 38, 25b-26a]

Bu minyatür (G. 19), bilge kişilerin ve onların temsil ettiği değerlerin yüceltilmesi anlamı taşımaktadır. Bu sahne ikonografik açıdan Kırk Vezir Hikâyeleri'nin nasihatname geleneğine özgü karakteristiğini, en bariz biçimde yansıtan örneğidir. Hikâyenin 
metninde vezirler, küçük şehzadeyi seçme nedenlerini: Hz. Muhammed'in hadisine uygun olarak orta yolu tercih etmesi, ulemaya layı olan tayinleri yapmasi, cahillere ne gerekirse onu vermesi olarak açıklarlar. Şehzadenin her birini inci gibi yerli yerine dizmesinin seçilmesinde etkili olduğunu belirtirler. ${ }^{41}$ Vezirlerin bu yorumu İslam kültüründe en genel hâliyle her şeyin yerli yerine konması anlamına gelen adalet kavramıyla örtüşmektedir. İslam bilginleri genel olarak adaleti, "denge ve orta nokta" olarak tanımlamaktadır. ${ }^{42}$ Bilginler şehzadeye birtakım sorular sormak için izin isterler. Eğer şehzade cevap verebilirse, bunu onun liyakatinin işareti olarak değerlendirebileceklerini belirtirler. İlk olarak "Sultan demek ne demektir?" diye sorarlar. Şehzade soruyu "burhânla ve hüccetle olana (sultan) derler" diyerek cevaplar ve ardından padişahların yeryüzünde Tanrı'nın gölgesi olduğunu ifade eder. "Adil kimdir?” diye sorduklarındaysa ilahi kanunlarla hükmeden şeklinde bir cevap vermiştir. ${ }^{43}$ Minyatür bu anlamda metinde idealize edilen yönetici imgesinin resim diliyle ifadesi olarak görülmelidir.

Kırk Vezir Hikâyeleri'nin iki nüshasında betimlenen tek peygamber öyküsü Uc bin Unk ve Hz. Musa arasındaki mücadeleyi ${ }^{44}$ (G. 20, G. 21) konu edinmektedir. Bu mücadele çerçeve hikâye içindeki bir iç hikâyede anlatılmaktadır. Hikâyeye göre Belam Baur ismindeki velinin vilayetine yakın bir yerde Ad kavminden kalmış kâfï bir taife vardır. Taifeden birinin ismi Uc bin Unk’tur. Hz. Musa asker toplayıp o kavmin üzerine yürür ve onları İslam'a davet eder. Uc, on kişilik elçi heyetini alıp torbasına koyar. Bu adamlar Hz. Musa'nın yanına dönünce askerlerin içine korku düşer. Hz. Musa asasını eline alır ve tek başına Uc'un üzerine gider. Uc hiddetlenip büyük bir dağı koparıp başının üstüne alır ve Hz. Musa’nın üzerine yürür. Bir ferişte (melek) kuş gagasıyla o dağı deler. Ve o delik Uc'un boğazına geçer. Uc'un boyu kırk arşın olmasına rağmen Hz. Musa siçrar ve peygamberlik kuvvetiyle onun topuğuna vurur ve Uc helak olur. ${ }^{45}$

41 Kırk Vezir Hikâyeleri, Vet. 38, 23a-26b.

42 Yunus Apaydın, “Adalet Nedir? Mahiyet ve Keyfiyet," Bilimnâme 35 (2018/1), 459.

43 Kırk Vezir Hikâyeleri, Vet. 38, 27a.

44 Uc hakkındaki rivayetlerin İsrâiliyat kaynaklı olduğu düşünülmektedir. Eski Ahid'de devlerden ve Nefilim (Nefhilim: iri adamlar) adı verilen eski zamanlarda yaşamış zorba ve meşhur adamlardan bahsedilmektedir (Tekvîn 6/4). Tevrat'ta uzunluğu dokuz arşın, eni dört arşın olarak verilen ve yatağı demirden olan Başan ülkesinin Amori kralı Og'dan söz edilmektedir (Tesniye, 3/11). Talmud ve Midraşlar'da Uc'a benzer tasvir edilen Og, Hz. İbrahim'in hizmetçisidir. Azat edilerek kral olmuş ve Sare'yi kaçırmak istediği için $\mathrm{Hz}$. Musa tarafından öldürülmüştür. Uc, kısas-1 enbiya geleneğinde de yer bulmuştur. Kisaî’ye göre, Hz. Musa Firavun'a elçi gönderdiğinde Uc da Firavun'un yanındadır. Firavun'un kızını almak için Beni İsrail yurdunu kayalarla yok etmek istediğinde, Allah'ın oraya hüdhüd kuşunu gönderir. Hüdhüd büyük bir taşı oyarak onun boynuna geçirir. Bu sırada yirmi zira uzunluğundaki $\mathrm{Hz}$. Musa yirmi arşın zıplayarak yirmi arşın uzunluğundaki asasıyla Uc'un ancak topuğuna kadar erişebilir ve onu öldürür. Bkz. Nebi Bozkurt, "Uc b. Unuk," Türkiye Diyanet Vakfi İslam Ansiklopedisi, c. 42 (İstanbul: Türkiye Diyanet Vakfi, 2012), 34-35.

45 Kırk Vezir Hikâyeleri, T. 7415, 39a-40b. 


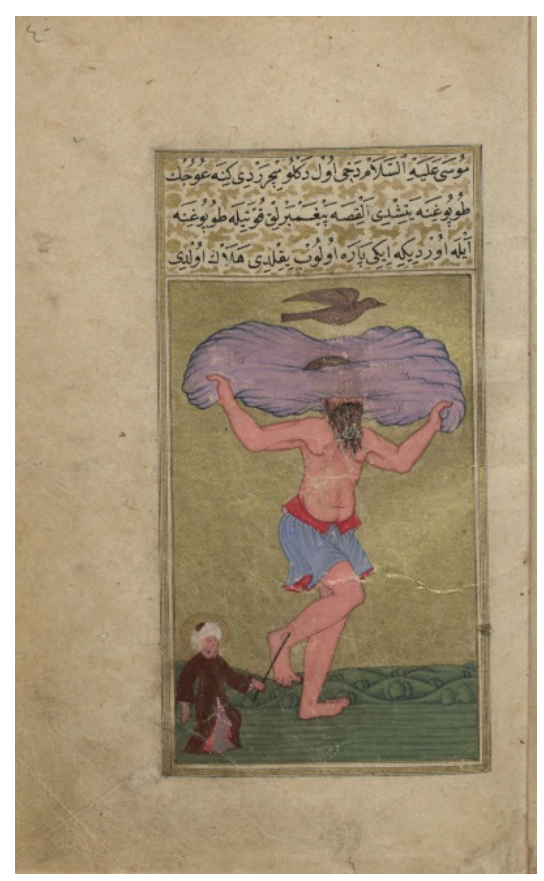

G. 20. Hz. Musa'nun Uc bin Unk'u mucize ile yenmesi [İ̈̈ T. 7415,40a]

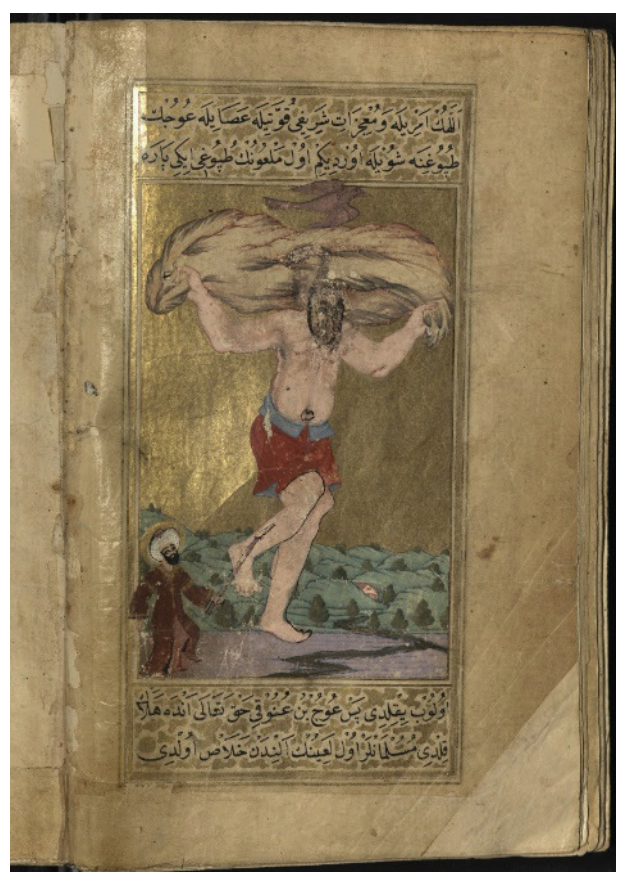

G. 21. Hz. Musa'nın Uc bin Unk'u mucize ile yenmesi, 1586-1587, [UUL Vet. 38, 35b]

Her iki minyatürde de dev Uc bin Unk minyatürün merkezindedir. Nakkaş A ve B devin vücudunun ayrıntılarını özenle belirtmiştir. Göbeğinde, kol kaslarında ve vücudun belli bölgelerinde derinlik verebilmek amaciyla yapılan gölgelendirmeler sanatçıların ustalık belgesi gibidir. Dağ başından geçtiğinden devin gözleri gözükmez. Mucizevi biçimde dağ 1 delen kuş, gökyüzünde kanat çırpmaktadır. Kahverengi bir cübbe giyen Hz. Musa ise başında peygamberlik işareti olarak dairevi bir hale taşır.

Nakkaşlar Musa'yı asasını Uc'un ayak bileğine indirirken betimlemiştir. Uc bin Unk'un Hz. Musa tarafından öldürülmesi, İslam edebiyatının farklı dönemlerinde kaynaklarda yer bulmuş bir hikâyedir. Hz. Musa ve Uc bin Unk arasındaki mücadeleyi gösteren bu ikonografi, İslam resim sanatının erken örneklerinden biri olan Reşideddin'in Camiü t-Tevarih isimli dünya tarihi niteliğindeki eserinin 1306-1307 tarihli resimli bir nüshasında [EUL, Ms. Arab 20,9a] da tasvir edilmiştir. ${ }^{46}$

Eserin İstanbul ve Uppsala nüshasında çerçeve hikâye içindeki iç hikâyelerden birine ayrılmış birer minyatürde (G. 22, G. 23.) yanlış bir karar alan şahı, ömrü boyunca acı çekmekten koruyan akıllı bir vezirin hikâyesi resimlenmiştir. Hikâye, Şah Cefakan'ı şehzadesini öldürme kararından vazgeçirmek için vezirlerden birinin

46 Joseph Gutmann ve Vera Basch Moreen, "The Combat between Moses and Og in Muslim Miniatures," Bulletin of The Asia Institute I (1987), 111. 
anlattığı hikâyedir. Hikâyeye göre bir ulu şah, onun üstün aklıyla bilinen bir veziri ve bu vezirin güzel yüzlü bir mahbub oğlu vardır. Şah da bu oğlana âşıktır. Bir gece şah mest hâldeyken bu oğlanı başka bir oğlanla oynarken görür ve öfkesine yenik düşüp oğlanın öldürülmesini diler. Cellat oğlanı dışarı çıkarır. Babasına haber verir. Vezir, cellada şahın sarhoş olduğunu, eğer oğlanı öldürürse şahın bu duruma kızacağını ve zindandan ölecek adamlardan birini getirip onun başını kesmesini söyler. Sabah olup da şah oğlanı sorunca kendisine oğlanın başının kesildiği söylenir. Şah bir iki ay hasretten ağlar. Vezir oğlunu çiçek gibi donatarak şaha götürür. Vezir, şaha “Allah senin bu ağlamalarını işitse, oğlanı diriltse, ne yapardın?” deyince, şah tüm varını vereceğini söyler ve başını eğip ağlar. Vezir oğlunu kolundan tutarak içeri getirir. Oğlan, şahın elini öper. Oğlanı görünce şahın aklı gider ve kendinden geçer. $^{47}$

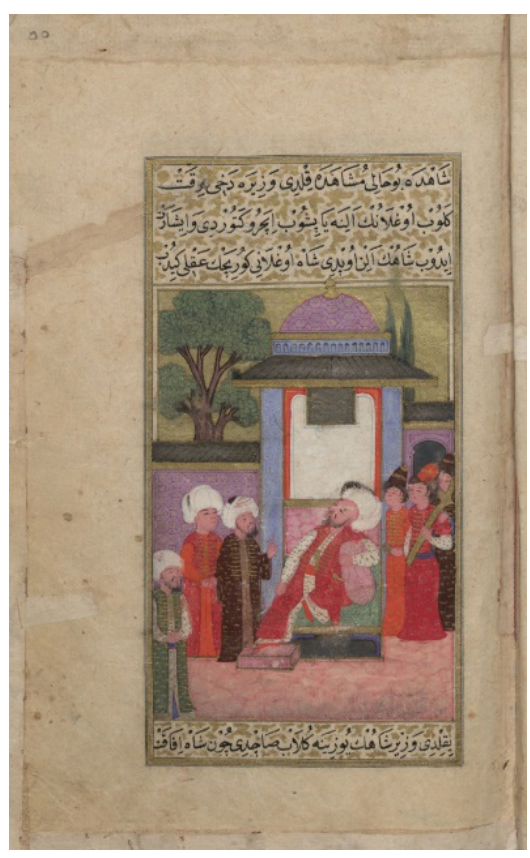

G. 22. Vezirin şahın aşığını huzura getirmesi, [İ̈̈ T. 7415, 55a]

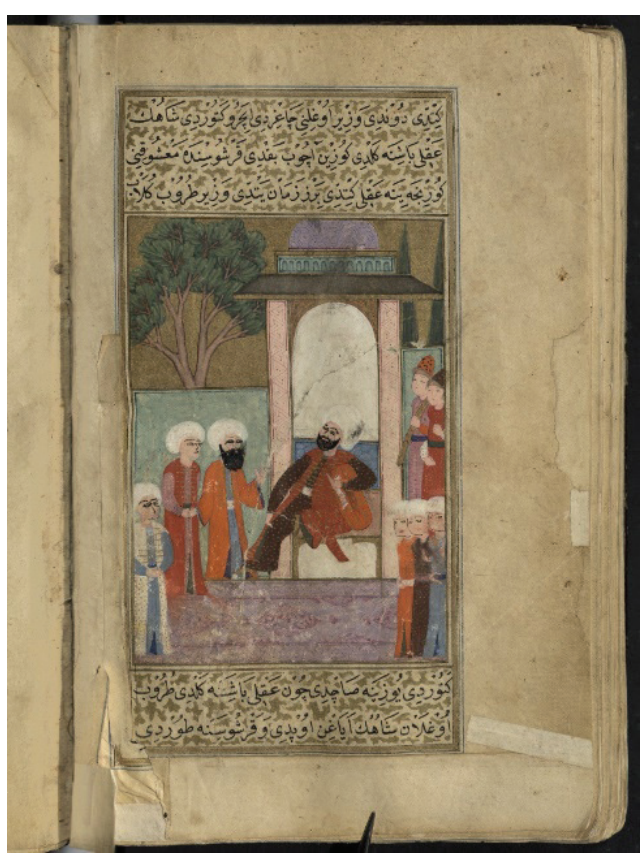

G. 23. Vezirin şahın aşı̆̆ını huzura getirmesi, 1586-1587, [UUL Vet. 38, 72b]

Her iki nüshadaki minyatür (G. 22, G. 23), sahnenin kurgusu açısından birbirine çok benzemektedir. Şah, kolsuz kaftanı, sorguçlu kavuğu, belinde kaması ve oturuş tarzıyla hakanî bir duruş sergilese de, nakkaşlar üzüntüden yıkılmış hâlini belirtmek için kavuğunu geriye doğru kaymış hâlde resmetmiştir. Vezir tahtın önünde şahla konuşmakta, oğluysa onun arkasında beklemektedir. Genç oğlanın yüzü tüysüzdür. Ellerini saygı işareti olarak önünde birleştirmiştir. Bakışları, padişaha yönelmiştir.

47 Kırk Vezir Hikâyeleri, T. 7415, 52b-55b. 
Pişman olunacak acele bir kararın mahsurlarını ifade etmek için anlatılan şah ve âşığ1 hikâyesine karşılık hatun, oğlan sözüne uymanın insanı kötü bir hâle düşüreceğini ispat için başka bir hikâye anlatır. Kırk Vezir Hikâyeleri'nin her iki nüshasında da betimlenmek için seçilen anekdot, Türk obasıyla ilgili bir iç hikâyedir. Türk obasının erkekleri pazara gitmiştir. Dönüş yolunda acıkırlar. Soğan ekmek yediklerinden gözlerinden yaşlar akar. Obanın oğlanları babalarını ağlarken görünce pazarda birinin öldüğünü düşünürler. Babalarına sormadan, obaya dönüp oradakilere "pazarda bir kimse ölmüş gibi babalarımız ağlaşıyor” derler. Bu haberi alan obanın kadınları feryat ederek eşlerine koşar. Erleri bu feryadı işitince obada bir adamın öldüğünü düşünüp yakalarını yırtarak gelirler. Kethüdalar araya girip meseleyi aydınlatır. Oğlan sözüne uydukları için bu hâle geldiklerini hepsi anlar. ${ }^{48}$

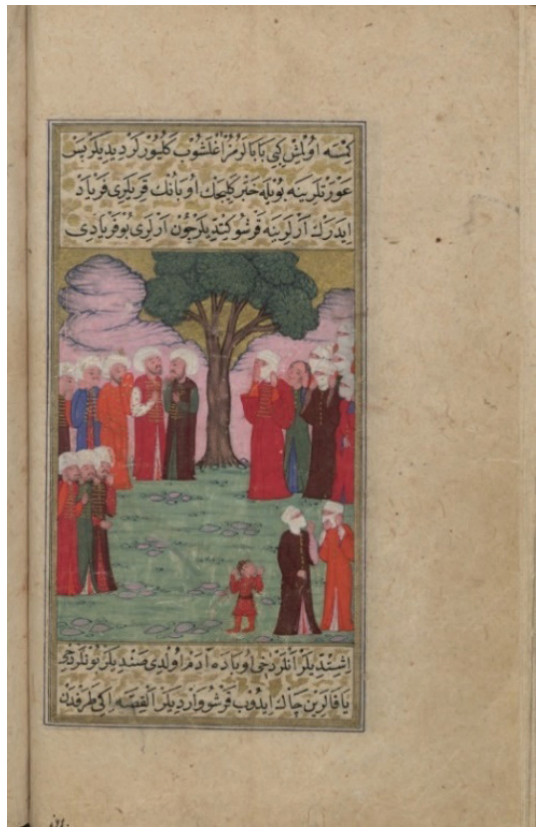

G. 24. Çocuğun sözüne uyan Türk obas1 kadınların ağlaşması, [Ï̈̈ T. $7415,89 \mathrm{~b}$ ]

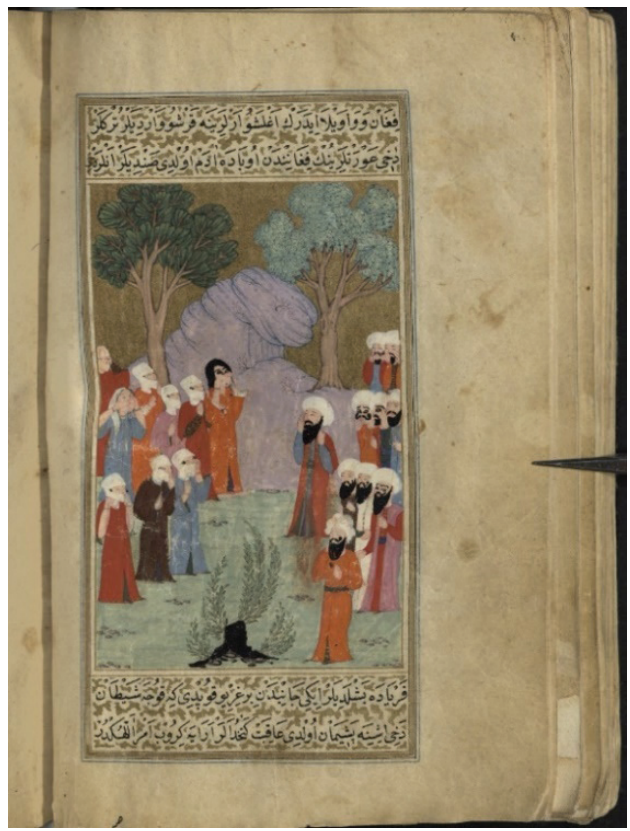

G.25. Çocuğun sözüne uyan Türk obası kadınlarının ağlaşması, 1586-1587, [UUL Vet. 38, 107b]

Minyatürlerde (G. 24, G. 25) Türk obasının kadınları kırlık bir yerde ağaçların önünde eşlerini karşılamaktadır. Kiminin eli yüzünde, kimi ise saç baş dağınık vaziyette feryat ederken tasvir edilmiştir. Resimlerde iki taraf arasında ölen olup olmadığını denetlemek isteyen ve anlaşmazlığı çözen kethüdaları diğer figürlerden ayırt etmek, çok mümkün değildir. Türk obasının erkeklerinde daha çok şaşkınlık hâkimdir. Eserin İstanbul nüshası minyatüründe (G. 24) sözleriyle obanın kadınlarının telaşa veren çocuklardan sadece biri betimlenmiştir. Uppsala minyatüründe (G. 25) sahnede çocuk yoktur. 
Bu minyatürlerden sonra eserin her iki nüshasında yine hatunun şahı ikna etmek için anlattığı bir hikâye betimlenmek için seçilmiştir. Minyatürlerle (G. 26, G. 27) bağlantılı hikâye, Arap şahı ve onun bir emiriyle ilgilidir. Şahın her salışında iki kuş tutan bir doğanı vardır. Emir Semhul, doğanın hünerini işitince şahla birlikte doğanı seyretmeye gider. Doğan, her avda iki kuş getirmektedir. Emir Semhul hayretler içinde doğanı övünce, şah doğanı emire hediye eder. Emir, kendisinin ve oğullarının artık şahın hizmetinde olduğunu söyler. Şah da buna cevaben doğanın değerinin şimdiden arttığını, önceden iki kuş tutarken şimdi bir bey ve beyin on iki oğluna bedel olduğunu belirtir. $^{49}$

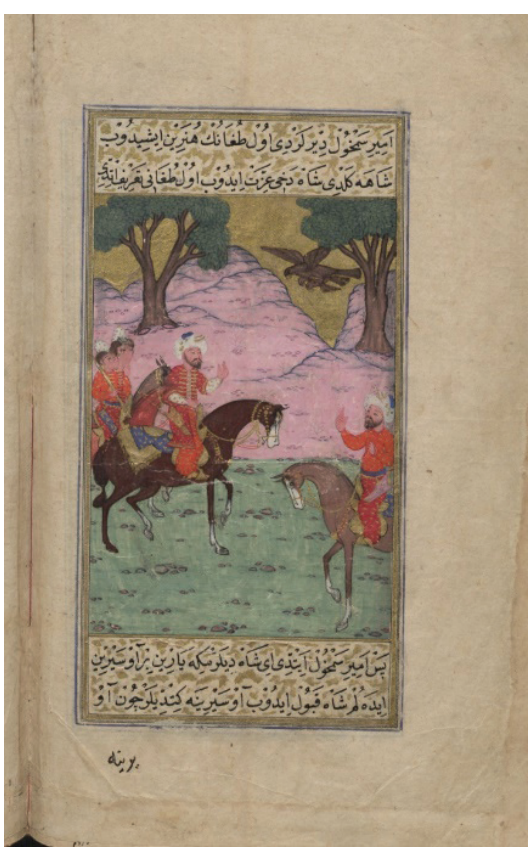

G. 26. Emir Semhul ile şahın bir doğanı izlemesi, [ïÜ T. 7415,124b]

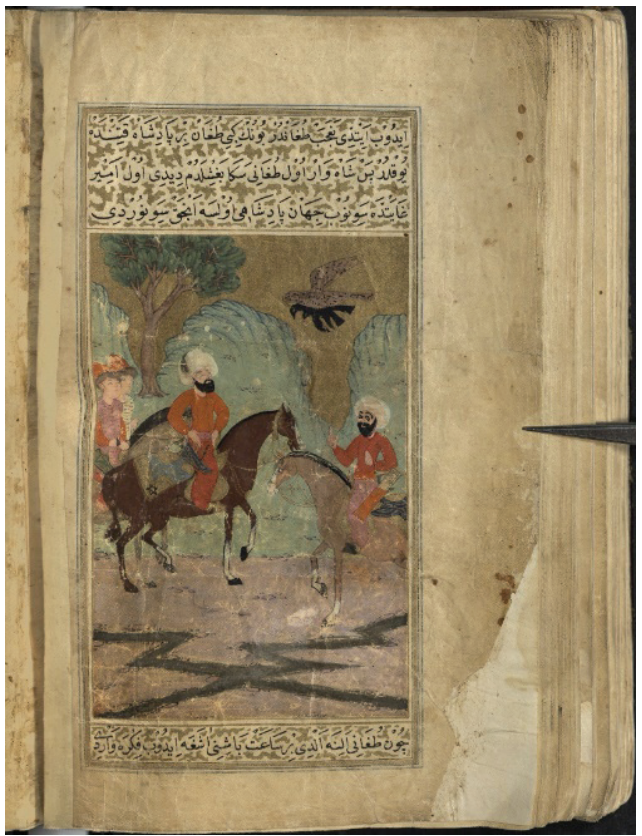

G. 27. Emir Semhul ile şahın bir doğanı izlemesi, 1586-1587, [UUL Vet. 38, 134b]

Kırk Vezir Hikâyeleri'nin hem İstanbul hem de Uppsala nüshasında yer alan minyatürlerde (G. 26, G. 27) Arap Şahı, süslenmiş kahverengi bir atın üzerindedir. Atın kuyruğu düğümlüdür. Eyeri ve koşum takımı özenle betimlenmiştir. Sırtında sadağı ve yayıyla ava gider hâlde resmedilmiştir. Şah, Emir Semhul ile konuşmaktadır. Gökyüzünde süzülen maharetli doğan tam da hikâyede belirtildiği üzere pençelerinde iki kuş taşımaktadır. İki resminde odak noktası şah ve emiridir. Minyatür, küçük bir cömertlik gösteren bir şahın karşılığında çok sadık adamlar kazanabileceği temasını işlemektedir. 


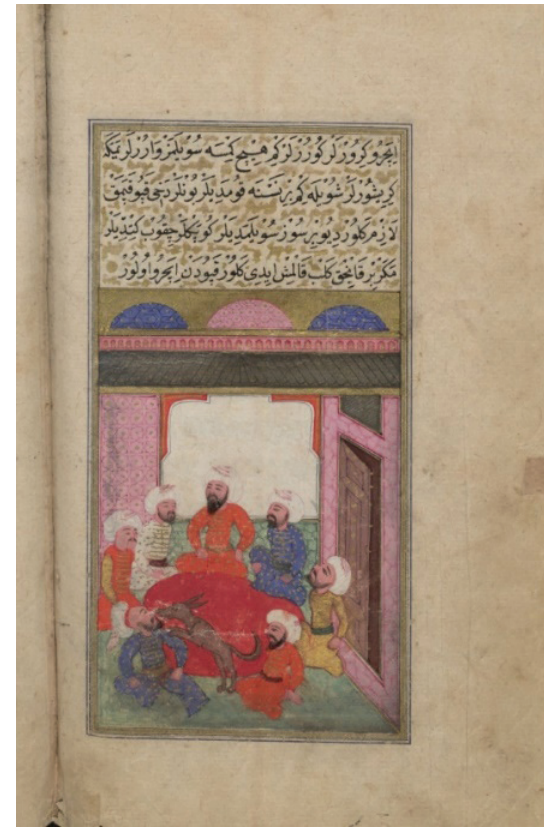

G. 28. Bir köpeğin yedi bengiden birini yaralaması, [İ̈̈ T. 7415, 141b].

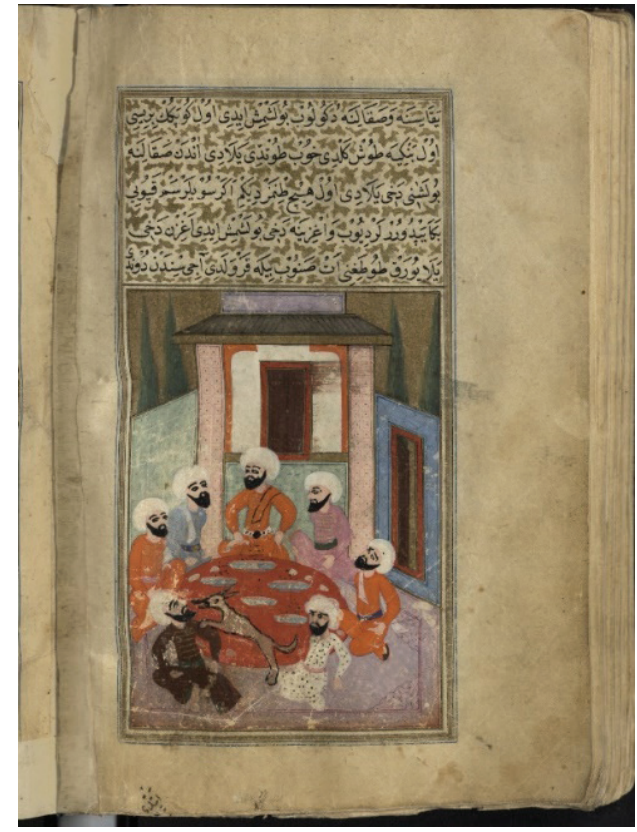

G. 29. Bir köpeğin yedi bengiden birini yaralamas1, 1586-1587, [UUL Vet. 38, 89b].

Kırk Vezir Hikâyeleri'nin her iki nüshasında çerçeve hikâyeye bağlı bir iç hikâyede yedi ölümsüzlerle ilgili bir anekdot betimlenmek için seçilmiştir. Yedi bengiler (ölümsüzler) hikâyesi, çerçeve hikâye içinde bir iç hikâyedir. Minyatürlerle (G. 28, G. 29) bağlantılı hikâyeye göre yedi bengiler nefis yemekler alıp bir eve girip otururlar. Kapıyı kapatmayı unuturlar ve kimin kapayacağı hakkında anlaşmazlığa düşerler. A $\breve{g}$ zından tek bir söz çıkanın kapatması hususunda anlaşırlar. Açık kapıdan giren köpekler, sofradaki her şeyi yer. Aralarında hiç biri ses etmez. Bir dişi köpek dışında diğer köpekler yedikten sonra dışarı çıkar. Dişi köpek de sofrayı biraz yalar. Aralarından biri heriseden (keşkek) bir kaşık almıştır. Keşkek de sakalına bulaşmıştır. Köpek önce sakalını yalar sonra adamın burnunu yahni sanıp 1sırır. Adam burnunun acısıyla feryat edince, konuştuğu için kapıyı onun kapatmasına karar verirler. Hatun hikâyedeki teşbih unsurlarını ve anlatma nedenini tek tek açıklar. Vezirlerin hikâyedeki köpekler gibi olduğunu, sofranın memleket olduğunu, köpek nasıl bengiyi ısırdı ise oğlanın da gelip şahı ısıracağını ve gafil avlanmaması gerektiğini söyleyerek ${ }^{50}$ şahı, oğlunu ve vezirlerini ortadan kaldırmaya teşvik eder. Kırk Vezir Hikâyeleri'nin her iki nüshasında yer alan minyatürde (G. 28, G. 29) inatları ve ahmaklıkları yüzünden yiyeceklerinden olan yedi ölümsüz bir odada sofra başında betimlenmiştir. Üşengeçlik yüzünden örtmedikleri kapı resmin sağında aralık haldedir. Ön planda köpeğin saldırısına uğrayan adam yer almaktadır. İstanbul nüshası tasvirinde (G. 28) sofra bezi üzerinde yiye- 
ceklere dair hiçbir iz yoktur. Uppsala minyatüründe (G. 29) ise sofra bezi üzerinde tabaklar ve yiyecek kırıntıları görülmektedir.

Kırk Vezir Hikâyeleri'nin sadece Uppsala nüshasında yer alan bir minyatür konusu itibariyle çerçeve hikâyeye aittir. On dokuzuncu vezir Şah Cefekân'a Hz. Adem'in oğullarından Habil ile Kabil'in hikâyesini anlatmış ve Kabil'in kardeşi Habil'i öldürme sebebini kadın meselesine bağlamıştır. Kadın sebebiyle nice kanların döküldüğünü fakat âlem şahlarının kan dökmesinin uygun olmadığını belirten bir nasihatla hikâyeyi tamamlamıştır. Vezir, Şah Cefakân’ın avrat sözüne uyup günahsız ciğer köşesine (şehzadesine) kıymamasını özellikle istemektedir. ${ }^{51}$ Kırk Vezir Hikâyeleri'nde sadece bu hikâyede değil, eserin genelinde kadınlara karşı oldukça şiddetli bir yergi söz konusudur. ${ }^{52}$

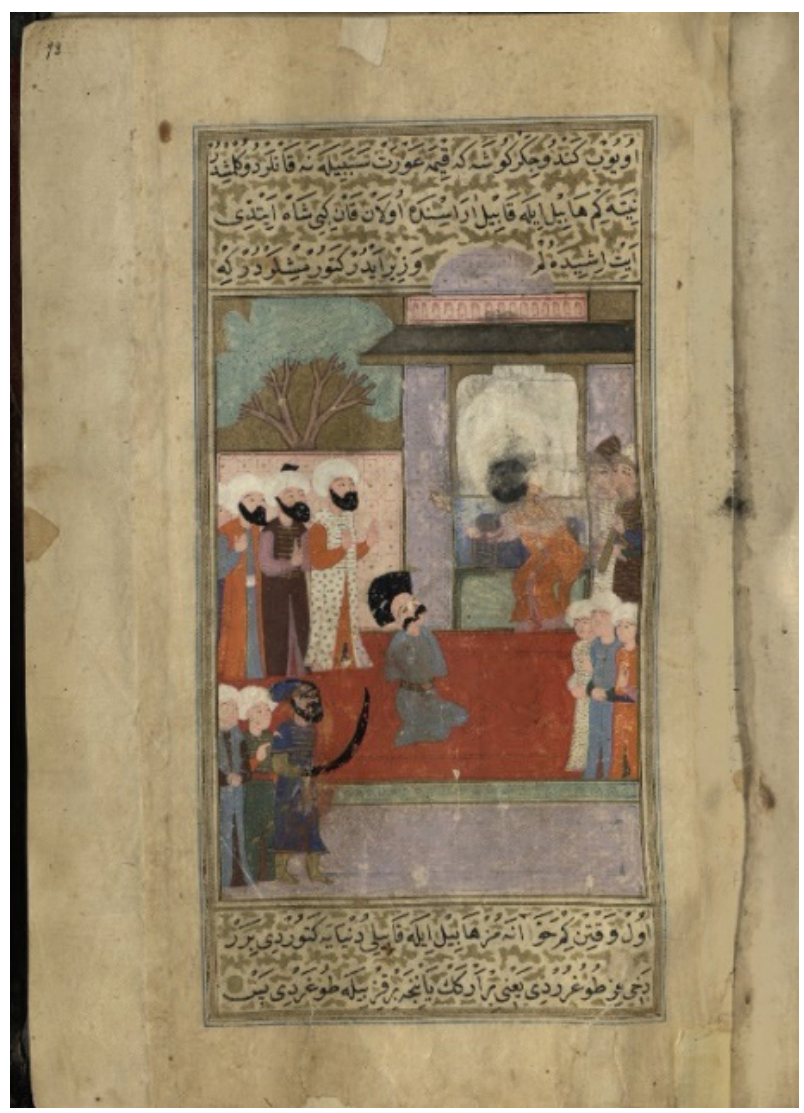

G. 30. Şahın şehzadesini cellat önüne çıkarması, Kırk Vezir Hikâyeleri, 1586-1587,

[UUL Vet. 38, 98a]

51 Kırk Vezir Hikâyeleri, Vet. 38, 97b-98b.

52 Hasan Kavruk, “Kırk Vezir Hikâyelerinde Kadın,” İstanbul Üniversitesi Edebiyat Fakültesi Türk Dili ve Edebiyatı Dergisi 30 (2003): 293. 
Bu hikâyeye bağl1 minyatürde (G. 30) vezirin nasihat ettiği Şah Cefekân'ın, şehzadesini cellat önüne çıkarması tasvir edilmiştir. Minyatürde sağda, tahtta oturan şahtır. Yüzünün olduğu kısım tahrip olmuştur. Şehzade elleri arkadan bağlanmış vaziyette diz üstü çökmüştür. Soldaki sıralı üç kişi şahı idamdan vazgeçirmeye çalışan vezirleri temsil etmektedir. Cellat ön planda elindeki kılıçla emir beklemektedir.

Kırk Vezir Hikâyeleri'nin Uppsala nüshasındaki on ikinci, İstanbul nüshasında ise son minyatür tuti (papağan) hikâyesine ayrılmıştır. Bu hikâyenin hilebaz karakteri bir şahı tuzağa düşürüp onun tahtına oturan bir vezirdir. Şah Cefakan'ın hatunu, şahı vezirleriyle ilgi olumsuz bir yargıya sürüklemek için bu hikâyeyi anlatmaktadır. Buna göre bir padişahın sarayına bir derviş gelir. Kendisinin bir dua bildiğini ve bu duayı okuyunca hangi surete isterse girebildiğini söyler. Şah, dervişten o duayı öğrenir. Bir gün vezirle şah ava çıkarlar. Vezir şahtan bu işin sırrını öğrenir ve şaha bu ölü papağanın suretine girip giremeyeceğini sorar. Şah papağanın suretine girer ve uçup ağaca konar. Vezir ise duayı okuyup şahın suretine girer, saraya gelir ve hatunla gece işret eder. Padişah suretindeki vezir tahta çıkar ve ülkeyi yönetir.

Bir gün bu papağan saray bahçesine gelir ve bahçıvana onu şehirde satmasını söyler. Bağban, tutiyi bir kafese koyar ve şehre götürüp hocalara arz eder. Herkes tuti ile latife eder. $\mathrm{O}$ şehirde bir avrat ${ }^{53}$ vardır. Her gecesi bin kızıldır (para). Bir gece düşünde bir hoca görür ve onunla sabaha kadar sohbet eder. Sabah olunca hocaya gidip bu gece kendisiyle sohbet ettiğini ve sohbetinin bedelinin bin filori olduğunu söyler, hocadan bin filorisini vermesini ister ve hocayı dava eder. Tuti bir kese altın ve ayna getirmelerini ister. Aynaya herkesin aksi düşer. Kese dahi aynada görünür. Papağan avrata ayna içindeki keseden hakkını almasını söyler. Avrat itiraz edince onun gibi sohbete böyle kızıl verirler der. Avrat hacil olur, utanır ve gider. Tuti bağbandan kendisini bin filoriden aşağı satmamasını ister. Bu haber şahın hatununa ulaşır ve hatun, tutiyi satın alır. ${ }^{54}$

53 H. Kavruk, Kırk Vezir Hikâyeleri'ndeki kadınları değerlendirdiği makalesinde bu hikayedeki kadın için "fahișe" kelimesini kullanır. Bkz. Kavruk, "Kırk Vezir Hikâyelerinde Kadın," 285. Fakat İstanbul ve Uppsala nüshalarında bu kelime geçmez. Onun yerine her iki nüshada bu kadından "avrat" olarak bahsedilmekte ve her iki nüshada da avrat gecelik sohbetinin bir bedeli olduğunu bildirmektedir. Bkz. Kırk Vezir Hikâyeleri, Vet.38, 153b; Kırk Vezir Hikâyeleri, T. 7415, 147b.

54 Kırk Vezir Hikâyeleri, T. 7415, 145a-148b. 


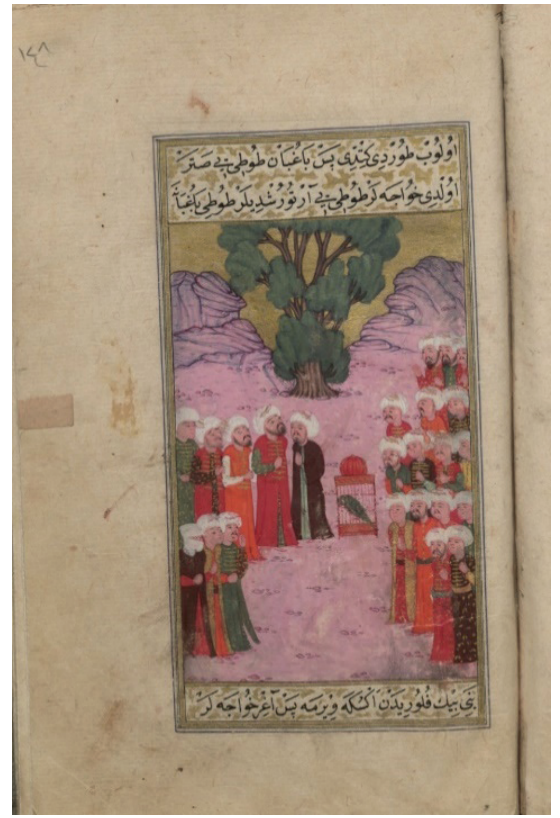

G. 31. Tutinin bir avrat hakkında hüküm vermesi ve bahçıvanın tutiyi satışa çıkarması, [ïÜ T. 7415,148a]

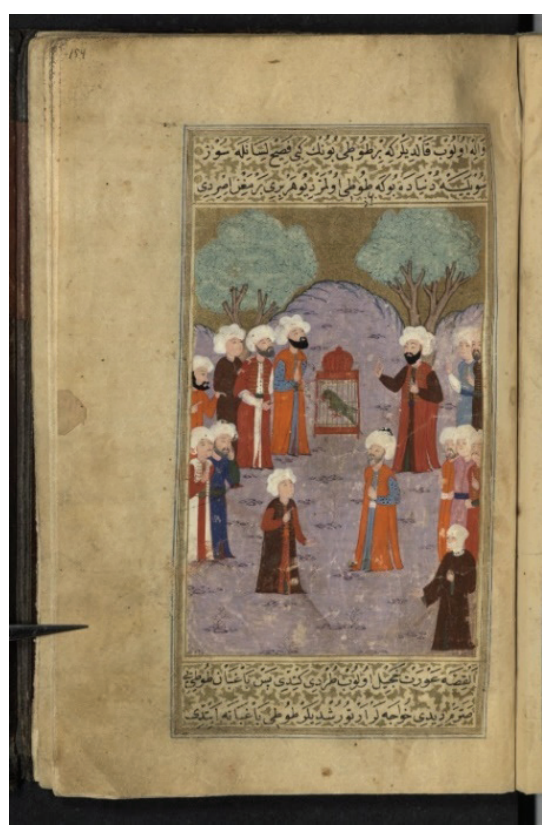

G. 32. Tutinin bir avrat hakkında hüküm vermesi ve tutinin bahçıvanı satışa çıkarması, 1586-1587,

[UUL Vet. 38, 154a]

Minyatürlerde (G. 31, G. 32) bir ağacın sağında ve solundaki tepelerin önüne yerleşmiş tek bir kadın dışında tamamen erkeklerden oluşan papağana talip olmuş bir alıcılar grubu yer almaktadır. Bağban ise kafesin yanında beklemektedir. Şahın bedenine girdiği yeşil papağan, kırmızı bir kafesin içindedir. Papağanla şakalaşan hocalar da bu açık artırmada hazır bulunmaktadır. Meclisteki tek kadının varlığı nakkaşların birbirini takip eden iki olayı aynı kare içinde gösterdiğini düşündürmektedir: Rüyasındaki yaptığı sohbetin parasını istemek için gelen kadına papağanın ders vermesi ve akabinde papağanın satışa çıkarılması. Her iki nakkaş da papağanın zekâsına işaret eden ayna ve kese unsurlarını atlamıştır.

Uppsala nüshasındaki on üçüncü minyatür (G. 33.), sadece Osmanlı minyatürü değil, İslam resmi açısından da çok özel bir sahnedir. Minyatürde Şah Cefakan'ın hatununun anlattığı bir iç hikâye tasvir edilmiştir. Hatun, Konstantiniyye tekfurunun pişmanlıkla sonlanan ve halkının zarar gördüğü bir hikâyeyi anlatarak şahı ikna etmeye çalışmaktadır. 


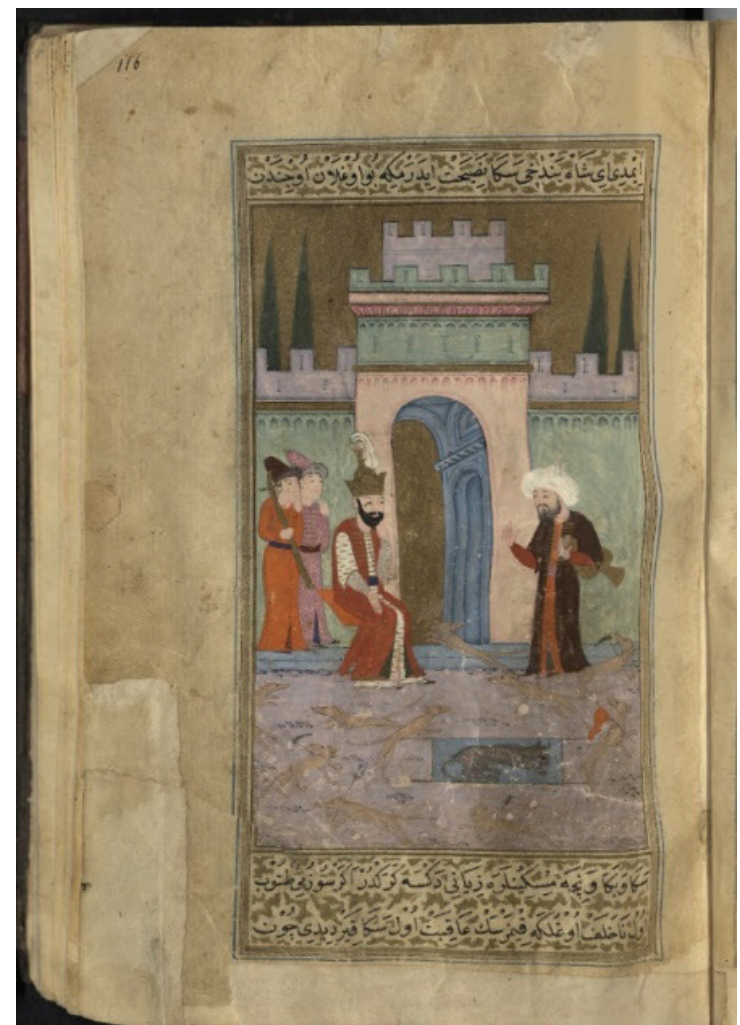

G. 33., Ebu Ali Sina'nın Konstantiniyye'yi basan farleri şehrin kapısından çıkarması, Kırk Vezir Hikâyeleri, 1586-87, [UUL Vet. 38, 116a].

Minyatürde (G. 33) Konstantiniyye surlarındaki bir kapıdan Ebu Ali Sina'nın efsun (büyü) söyleyerek sıçanları çıkarması konu edilmiştir. Ortaçağ tıbbının önde gelen temsilcisi ve hikâyede Ebu Ali Sina olarak geçen bu filozofun tam ismi, Ebu Ali elHüseyin b. Abdillah b. Ali b. Sina (ö. 1307)'dır. Ebu Ali Sina, Gali Sina ve Ebâli Sinan olarak da isimlendirilmektedir. İbn Sina hakkında sözlü ve yazılı kaynaklarda masal, efsane, halk hikâyesi gibi anlatılar bulunmaktadır. ${ }^{55}$

Minyatürle bağlantılı hikâyeye göre Ebu Ali Sina, Konstantiniyye tekfurunun katına varmıştır. Ne tekfurun ne de halkın huzuru vardır. Şehri sıçanlar basmıştır. Ebu Ali Sina, tekfura şartı yerine gelirse şehirde tek bir sıçan kalmayacağını söyler. Tekfurdan şehrin kapısında durmasını ve ne acayiplik görürse görsün gülmemesini söyler. Tekfur atına atlayıp şehir kapısında durur. Ebu Ali Sina gelir ve beş sıçan tutar, bu sıçanlardan birini öldürür. Ve onu bir salacaya (sedyeye) koyar. Sedyeyi de dört sıçana bağlar. Siçanlar sedyeyi aheste aheste götürür. Ebu Ali eline bir dünbeki (dümbelek) alıp onların ardınca çala çala gider ve efsun okur. Şehirde ne kadar sıçan varsa hepsi

55 Ebru Şenocak, "Halk muhayyilesinde İbn Sina ve Hayatı Hakkında Anlatılan Efsaneler," Akra Kültür Sanat ve Edebiyat Dergisi 8 (2016), 160. 
o cenazeye katılır. Sıçanlar tekfurun durduğu yerden kapıdan dışarı çıkarlar. Tekfur, o dört sıçanın cenaze getirdiklerini gördüğü an gülmeye başlar. Tekfur gülünce içeride bulunan sıçanlar yine içeri dağılır. Dışarıda bulunanlar ise yine dışarıda kalır. Ebu Ali, tekfura gelip "Eğer nasihatimi tutup bize gülmeseydin, tüm memleket halkı sıçan zahmetinden kurtulmuşlard1," der. Tekfur, yaptığ 1 şeye pişman olur. ${ }^{56}$

Nakkaş B minyatürde (G. 33) Konstantiniyye'yi surlarla temsil etmektedir. Sur kapısının dışında selvi ağaçlarını, içerde ise Konstantiniyye tekfuru ve iki saray görevlisini resmetmiştir. İbn Sina, tekfurun karşısındadır. Efsunlu sözler söyleyerek çaldığ 1 dümbeleği koltuğunun altında taşımaktadır. Resmin ön tarafındaki istilacı sıçanlar büyünün etkisiyle bir cenaze alayı düzenlemektedir. Bir köpek kadar iri betimlenen bu sıçanlardan ikisi sedye üzerinde bir sıçanı taşımaktadır. Sedyenin önündeki sıçanın elinde, genelde cenazelerde taşınan bir sancak yer almaktadır. Bazı sıçanların ellerinde çekice benzer aletler görülür. Minyatür, İslam kültüründe tıpçı ve filozof kimliğiyle anılan İbn Sina'yı sıçanları efsunlarken tasvir etmektedir. İbn Sina'nın fareler tarafından istila edilen şehirleri kurtarması, Kırk Vezir Hikâyeleri dışında da rastlanan bir hikâyedir. Fakat o hikâyelerde mevzubahis olan şehir Konstantiniyye değil Halep'tir. ${ }^{57}$

Kırk Vezir Hikâyeleri'nin Uppsala nüshası çift sayfa minyatürle son bulmaktadır. Minyatürlerin konusu eserin çerçeve hikâyesinin son bölümüdür. Minyatür (G. 34) ile bağlantılı metinde şah hatunun sözünü kabul eder, sabah olunca tahta geçer ve cellada oğlunu hazır etmesini söyler. Önce kırk vezirinin elinin bağlanmasını ve sonra oğlunun boynunun vurulmasını ister. Cellat oğlanın gözünü bağlar ve destur ister. Oğlanın boynuna kılıcı vuracağ1 zaman şehzadenin hocası gelir. Hoca konuşmama tembihinin kendine ait olduğunu bildirir. Şehzadeye artık konuşabilirsin dediğinde şehzade besmele çeker ve anlatmaya başlar. Hatunun, şahı hazinedeki türlü zehirlerle öldürmeyi teklif ettiğini, kendisi cevap vermeyince de kolunu boynuna dolayıp onu öpmeye çalıştığını ve elinin arkasıyla hatuna vurduğunu anlatır. Bunun üzerine hatunun hışma gelip "Bre alık oğlan ben seni tahta geçirip padişah edeyim derim, sen bana böyle mi edersin. Babana söyleyeyim her parçanı ayırsın," dediğini şaha bildirir. ${ }^{58}$

56 Kırk Vezir Hikâyeleri, Vet. 38, 115a-116b.

57 Hikâyeye göre “Halep'i sıçanlar istila etmiş ve Halep sultanı, İbn Sina'dan bunları ortadan kaldırma yönünden bir çare bulmasını rica etmiştir. İbn Sina da sultana "Bir şartım var. Şehrin kapısında duracak ve gördüklerinize hiç gülmeyeceksiniz”, der. Bu şartı kabul eden sultan atına atlayıp şehrin kapısına gidip beklemeye başlamış. İbn Sina yaptığı sihirle sıçanları ortaya çıkarmış ve bunlardan birini öldürüp bir tabuta koymuş ve dört sıçana yükletmiş. Bir el çırpmasıyla tabutu yüklenmiş dört sıçan şehrin kapısına doğru yürümeye başlamış. Şehirde ne kadar sıçan varsa onları takip etmeye başlamış. Kapıya geldikleri zaman, tabut taşıyan sıçanları gören sultan dayanamayıp gülmüş. Bu anda kapıdan çıkan sıçanların hepsi ölmüş, içeride kalanlar tekrar şehrin içine taşınmış. İbn Sina "Ey sultan eğer nasihati tutup, bir an gülmeseydin bu şehirde bir tane canlı fare kalmayacaktı”, demiş. Sultan güldüğüne pişman olmuş fakat sonuç değişmemiş.” Bkz. Ali Haydar Bayat, "Türk-İslam Toplumlarında İbn Sina Hikâye ve Fıkraları," Uluslararası İbn Sina Sempozyumu Bildiriler (Ankara: Kültür ve Turizm Bakanlığı Milli Kütüphane, 1984), 581.

58 Kırk Vezir Hikâyeleri, Vet. 38, 163a-163b. 


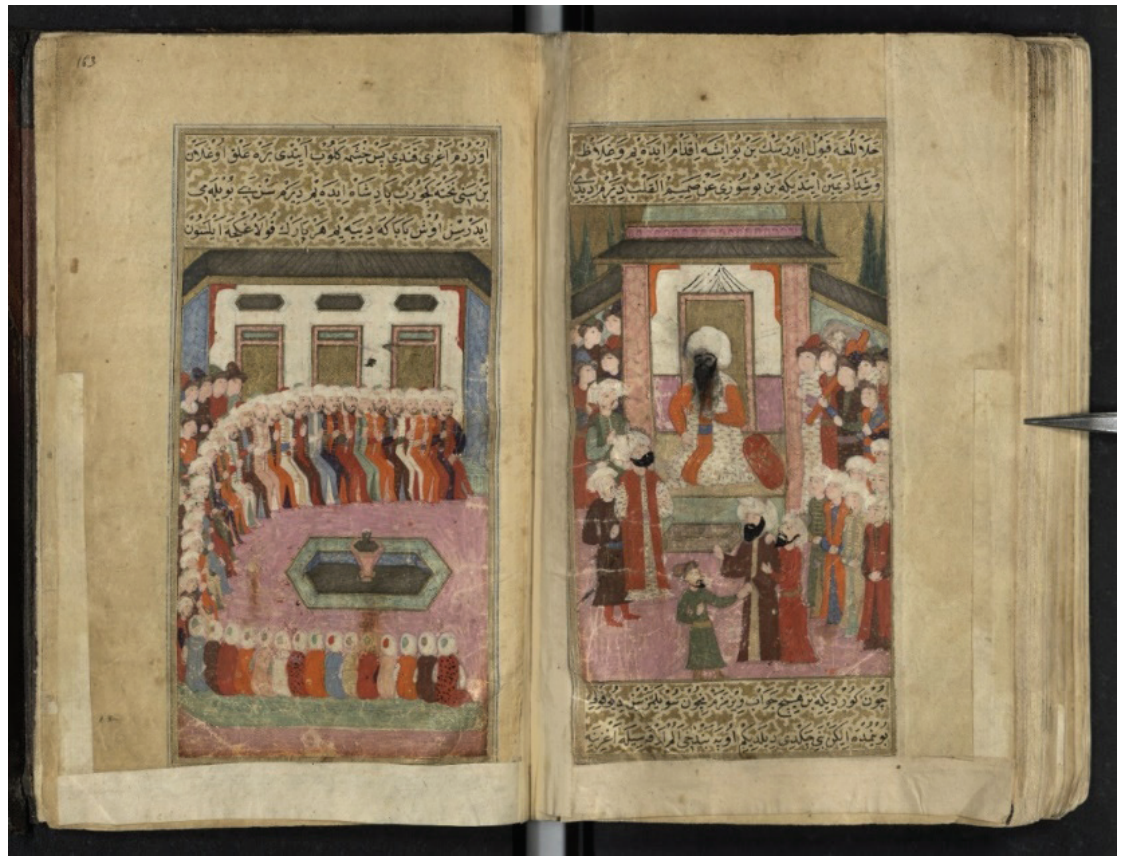

G. 34. Şehzadenin idamı sırasında hocasının şahın huzuruna gelmesi, Kırk Vezir Hikâyeleri, 15861587 ,

[UUL Vet. 38, 162b-163a].

Minyatür (G. 34) şehzadenin idam anında yaşadıklarını tasvir etmektedir. Kırk günlük konuşma orucu tutan şehzade, tahtta oturan şahın önünde elleri arkadan bağlanmış vaziyette duran genç adamdır. Başını şaha doğru kaldırmıştır. Şehzadeye orucunun bittiğini haber veren hocası, ön plandaki kahverengi cübbe giymiş kişidir. Şahın iki adamı onu engellemeye çalışmaktadır. Şehzadenin yanında duran ve kuşağından uzun bir kılıç sarkan genç adam cellattır. Şahın ellerinin bağlanmasını emrettiği kırk veziri, karşı sayfada yeşil örtülü bir sedir üzerinde oturmaktadır. Hilal şeklinde oturmuş bu kırk figürün tek elleri havadadır. Bu durumu, vezirlerin ellerinin bağlanmasına bir gönderme olarak yorumlamak mümkündür. Havuzun etrafına dizilmiş vezirlerin ve şahın arkasında olayı izleyen genç saray görevlileri ve onların önlerinde sıralanmış bir grup genç erkek dikkat çekmektedir.

\section{Kırk Vezir Hikâyeleri Minyatürlerinde Üslup ve İkonografi}

Kırk Vezir Hikâyeleri nüshalarının minyatürlerinde, figürlerin sahneye yerleştiriliş biçimi, resimlenecek yüzeyin şematik düzenle ele alınması ve renk anlayışı aynıdır. Her iki nüshada kullanılan ortak renkler: kırmız1, pembe, eflatun, turuncu, sar1, kahverengi, mavi, yeşil ve eflatun tonlarıdır. Fakat lacivert, sadece Uppsala nüshas1 minyatürlerinde görülmektedir. Üzerine yıldızlar serpiştirilmiş gecenin rengini gösteren (G. 17) lacivert tonuna, bu nüshanın birkaç minyatüründe hem kıyafet- 
lerde (G. 18, G. 32) hem de daha küçük yüzeylerde rastlamak mümkündür. Ayrıca serlevha tezhibinde (G. 8) kullanılan bordo renk sadece bu nüshanın minyatürlerine özgüdür. Minyatürlerde (G. 12, G. 13, G. 18, G. 19, G. 22, G. 23, G. 34) şah karakteri, üzeri kubbeyle örtülü bahçe köşkünü andıran bir binada kolunun altında bir yastıkla oturur vaziyette resmedilmiştir. Bu köşkün, şahın arkasında kalan, genelde biri küçük, diğeri büyük olmak üzere iki düşey pencereyle süslendiği görülür. Özellikle eserin Uppsala nüshasına ait bazı minyatürlerinde (G. 11, G. 13, G. 17) üst pencerenin üzeri, tezyin edilmiş sık bir kafes ile kapatılmıştır. Bu mimari ve şahın mimaride konumlanışına ilişkin bu şablonu, Nakkaş Osman'ın elinden çıkan 1581 tarihli Şehinşahnâme'nin I. cildinde [İstanbul Üniversitesi Kütüphanesi, F. 1404, 134b] yer alan bir sahnede de (G. 35) görmek mümkündür. Tasvirde (G. 35) Sultan III. Murad'ın Bursa kemeriyle tamamlanmış kubbeli bir yapıda oturması ve üstteki kafesli pencere, üslup açısından öne çıkan benzerliklerdendir.

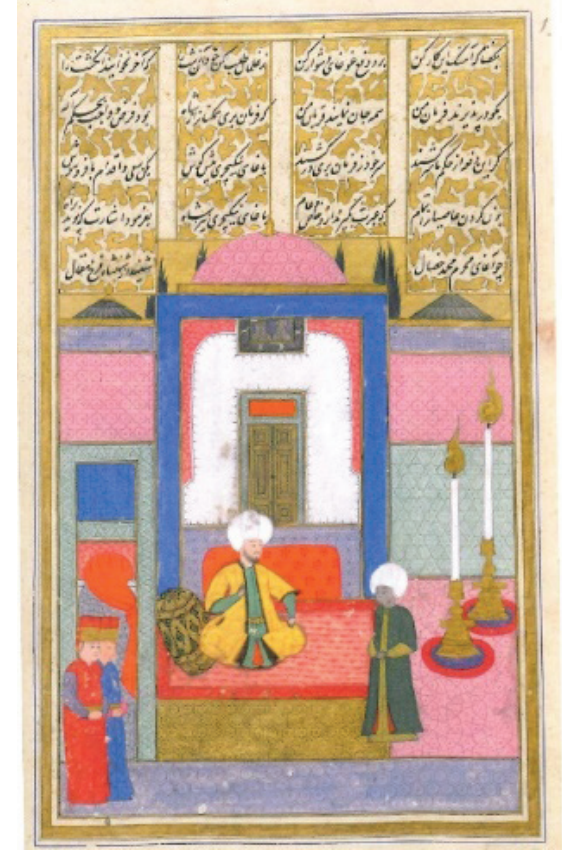

G.35. Mehmed Ağa'nın Sultan III. Murad'a bilgi vermesi, Şehinşahname I, 1581, [İÜK F. 1404, 134b], E. Fetvac1, 2013, G. 4.0.4

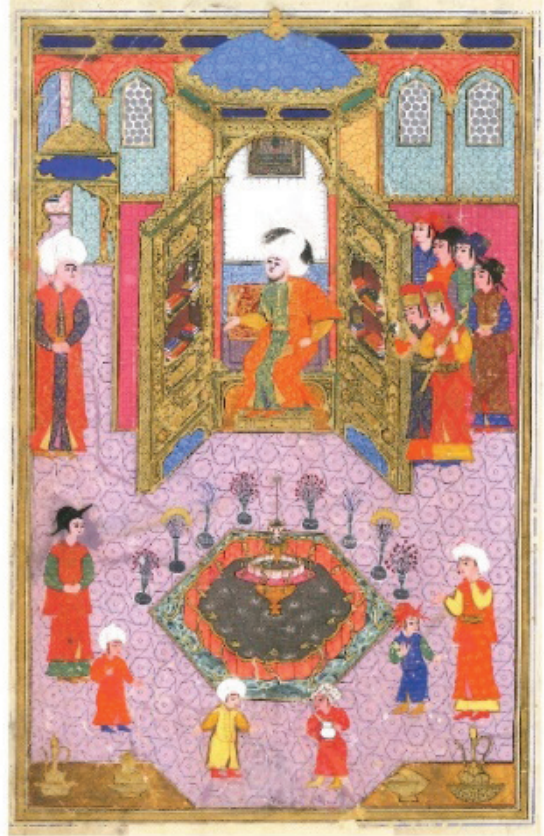

G. 36. Sultan III. Murad kütüphanesinde, Cevâhir'ül Garaib fi Tercümet Bahr'ül Acaib, 1582, Harvard Sanat Müzeleri

Türk Sanatı Koleksiyonu 1985. 219.2, E. Fetvac1, 2013, G. 1.02.

Her iki nüshadaki minyatürlerinin Osmanlı resminin klasik üslubuna yakınlı̆̆ sadece resim alanının değerlendirilmesiyle sınırlı değildir. Uppsala nüshasındaki G. 13 'te şahın önündeki havuza su taşıyan dört fiskiyenin lale formu, Nakkaş Osman'ın ekibindeki sanatçılardan birinin elinden çıktığı düşünülen, 1582 tarihli Cevâhir' 'ül 
Garaib fi Tercümet Bahr'ül Acaib isimli eserde ${ }^{59}$ Sultan III. Murad'ı kütüphanesinde gösteren resimdeki (G. 36) fiskiyelere çok benzemektedir. Kırk Vezir Hikâyeleri betimlemelerinde kubbeyle saçak arasında kalan kasnak kısmında bazen de saçakların altındaki silmelerde (G. 12, G. 13, G. 14, G. 15, G. 34) daha koyu tonlarla derinlik verilerek bezendi görülür. Mimari unsurların böyle bezenmesine Osmanlı minyatürünün klasik üslubunda 1582 tarihli yine Nakkaş Osman ve ekibinin elinden çıkan bazı Surnâme minyatürlerinde (G. 37) rastlamak mümkündür. Surnâme minyatürlerindeki renk anlayışıyla Kırk Vezir Hikâyeleri’nin her iki nüshasının renkleri de çok yakındır. Üsluptaki benzeşme figür tiplerini de kapsamaktadır.
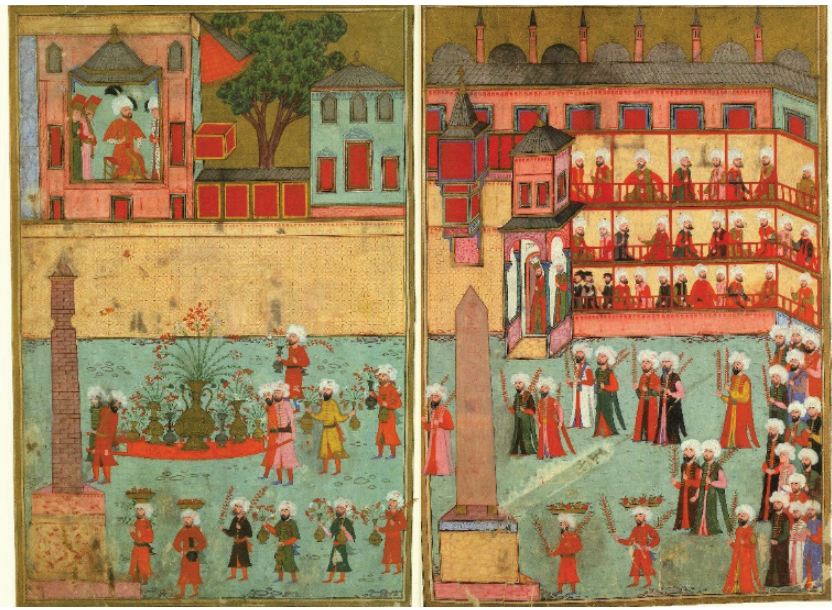

G. 37. Bahar satıcıların geçişi, Surnâme-i Hümayun, 1582, [TSMK, H.1344, 34b-35a], Atasoy, 1997, 40-41.

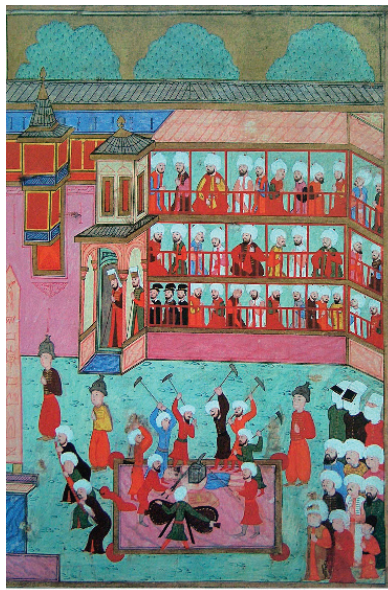

G. 38. Demircilerin geçişi, Surnâme-i Hümayun, 1582, [TSMK, H.1344, 291a].

59 Cevâhir'ül Garaib fi Tercümet Bahr'ül Acaib isimli eser Mustafa Cenâbî tarafından kaleme alınmıştır. Daha önce Edwin Binney Koleksiyonu'nda yer alan bu nüshanın Sultan III. Murad için hazırlandığı ve Nakkaş Osman'ın ekibindeki sanatçılardan biri tarafından resimlendiği düşünülmektedir. Bkz. Mahir, Osmanlı Minyatür Sanatı, 60. 
Kırk Vezir Hikâyeleri'nde çerçeve hikâyede gerçek bir zaman diliminden bahsedilmeden bir şah, kırk veziri, eşi ve şehzadesinin hikâyesi anlatılmaktadır. Fakat her iki eserin nakkaşları bu karakterleri giyinişleri ve onları saran çevre açısından Osmanlılaştırmıştır. Bu durum özellikle her iki nüshanın kadın giyiminde (G. 14, G. 15, G. 24, G. 25, G. 31, G. 32) açıkça görülmektedir. Kadınlar, XVI. yüzyıl sonu Osmanlı kadınının görünüşü üzere tasvir edilmiştir. Dış mekân sahnelerindeki rengârenk feraceler, küçük bir başlık üzerine dolanan beyaz örtü, beyaz yaşmak ve kimi zaman yarım bir peçeden oluşan başörtüler, Surnâme minyatürlerindeki (G. 37) gösterileri izleyen halktan kadınların görünüşüyle çok benzerdir.

Kırk Vezir Hikâyeleri İstanbul nüshası sanatçısı Nakkaş A'da tüm figürlerin yüzleri, elleri kısacası tenleri çok açık bir pembeyle boyanırken, Uppsala nüshası sanatçısı Nakkaş B gerçeğe daha yakın olacak biçimde ten rengini kullanmaktadır. Bu farklılık, Uc bin Unk'un (G. 20, G. 21) tasvirinde açıkça bellidir. Ayrıca bu sahnede Nakkaş B (G. 21) metinden bağımsız olarak, izleyiciyi hoş bir manzarayla baş başa bırakır. Tepelere yerleşmiş ağaçlar ve tepelerin arasından sadece bir kısmı görünen kırma çatılı bir ev ve onun önündeki değirmen, resmin ön planına doğru akan gümüş ırmak, nakkaşın manzaraya kattığı ve onun sanatı hakkında fikir veren detaylardır. Nakkaş B derinlik vermek hususunda da başarılıdır. Konstantiniyye surlarındaki kapının kemerine (G. 33) ve hamam giriş kemerine (G. 15) tonlama ve çizgilerle verdiği derinlik ustacadır. Bu nakkaş, mimarinin tasvirinde daha detaycı bir yaklaşım sergilemektedir. Nakkaş B, hamam (G. 15) mimarisinde var olan detayları, Nakkaş A'nın betimlemesine (G. 14) göre daha gerçeğe uygun bir biçimde ele almıştır. Hamam kubbeleri üzerindeki camla kapatılmış aydınlatma gözlerini resimlemiştir. Nakkaş B'nin figürleri, Nakkaş A'ya nazaran (G. 10 ve G. 11) daha iridir. Nakkaş A ise diğer sanatçıya nazaran daha ince bir işçilikle çalışmıştır. Yüzleri betimlemekte (G. 12, G. 16) çok mahirdir. Çok ince taranmış sakallar ve bıyıklar ve özellikle yüz tipolojisindeki çeşitlilik onun en bariz vasfıdır. İnce, uzun ve narin figürleri vardır. Her iki sanatçı metinle çok uyumlu resimler üretmiştir. Hikâyede yer alan detaylar Osmanlı resim dünyasının hazır imgeleriyle bütünleşerek resimlenecek yüzeye aktarılmıştır.

Kırk Vezir Hikâyeleri minyatürleri iki sahne hariç ikonografik açıdan özgündür. Minyatürler içinde İslam resminde daha önce var olan bir ikonografinin tekrar edildiği sahnelerden ilki Hz. Musa'nın Uc bin Unk'u mucize ile yenmesine ait (G. 20, G. 21) tasvirlerdir. Dev Uc ile Hz. Musa arasındaki mücadelenin tasvirine ilişkin ilk örnekler İslam sanatında XIV. yüzyıla kadar gitmektedir. Kırk Vezir Hikâyeleri tasvirleri içinde Şah Cefekân'ın karısının şehzadeyi kandırmaya çalıştığı sahneler (G. 10, G. 11) ikonografik açıdan Sinbadnâme'deki bir minyatür ile yakınlık göstermektedir. Sinbadnâme çerçeve hikâyelerin konuları açısından Kırk Vezir Hikâyeleri ile çokça benzeşen edebi bir eserdir. 


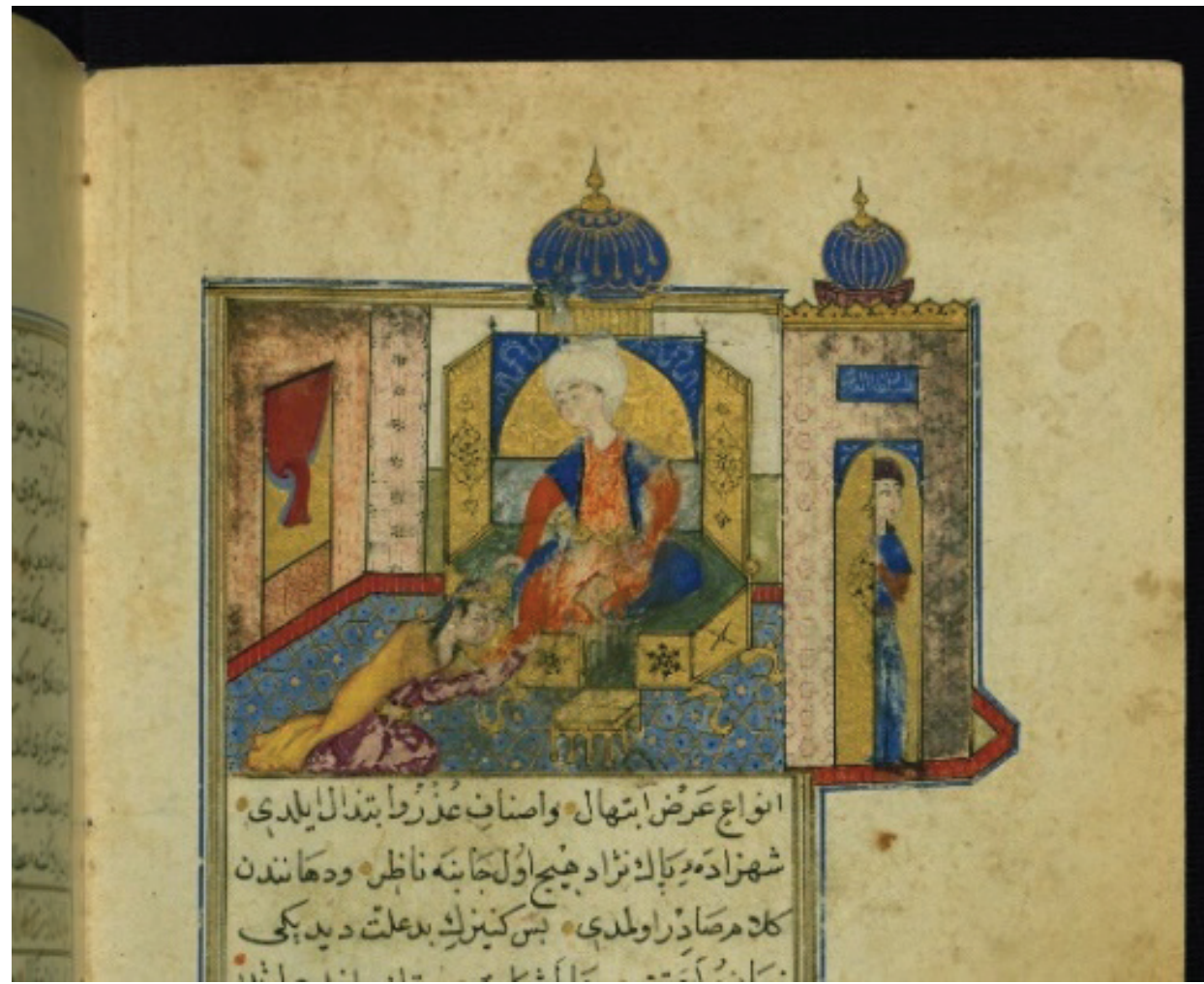

G. 39. Cariyenin şehzadeyi baştan çıkarmaya çalışması, Tuhfetü'l Ahyar, Walters Art Gallery Baltimore, [W 622, 12a], G. Renda, 2004, s. 312.

Osmanlı sanatında şu ana kadar bilinen resimli tek Sinbadnâme çevirisi Baltimore'da Walters Art Gallery'de W.662 numarada Tuhfetu'l Ahyar ismiyle kayıtlı nüshadır. Eserin colofonu yoktur. ${ }^{60}$ Sinbadnâme' de yer alan bir minyatürde (G. 39), şehzade haremde bir taht üzerinde oturmaktadır, tahtın önünde diz çökmüş cariye ise onun eteğini tutmaktadır. Sahnede şehzadenin konuşmama sebebini öğrenmek isteyen şahın hanımlarından veya cariyelerinden birinin, şehzadeye duyduğu aşkı itiraf etme anı betimlenmiştir. Hikâyeye göre cariye, şehzadeye eğer bu durumu itiraf ederse onu kral yapabileceğini söyler. Konuşmaması gereken şehzade o an gaflete düşerek bu işin nasıl olacağını sorar. Cariye, "padişahı zehirleyerek" diye cevap verir. ${ }^{61}$

Kırk Vezir Hikâyeleri'nin her iki nüshasının minyatürlerinde, ortak ikonografyayı paylaşan on minyatür mevcuttur. İstanbul nüshasında çerçeve hikâyeye ayrılmış iki minyatür (G. 10, G. 12) bulunurken, eserin Uppsala nüshasında çerçeve hikâyenin girişi, ilerleyişi ve sonuç anı betimlenerek, bir anlamda tüm "macera"

60 Günsel Renda, "Sinbadnama: An Early Ottoman Illustrated Manuscript Unique in Iconography and Style," Muqarnas 21 (2004), 311.

61 Renda, "Sinbadnama: An Early Ottoman Illustrated Manuscript Unique in Iconography and Style,” 314. 
okuyucunun imgelemi gözetilerek, resim diliyle özetlenmiştir. Uppsala nüshası minyatürleri, Şah Cefakan'ın karısının şahı aldatma teşebbüsü ve şehzade tarafından bu durumun reddedilmesi ile başlamış (G. 11), hatunun eline yüzüne kan bulaştırarak şehzadeyi şaha şikâyet etmesi (G. 13) ve şahın şehzadesini cellat önüne çıkarmasıyla (G. 30) devam etmiştir. Son olarak şahın tekrar idam kararı vermesi üzerine, üstadın gelerek şehzadeyi cellattan kurtarma sahnesi (G. 34) ile son bulmuştur. Fakat eserin İstanbul nüshasında çerçeve hikâyeye ayrılmış sadece iki sahne (G. 10, G. 12) mevcuttur.

Kırk Vezir Hikâyeleri'nin her iki nüshasında yer alan minyatürlerde bir diğer ikonografik kategori keramet sahneleridir. İşrakilik düşüncesinin en büyük filozoflarından Şeyh Şehabeddin Sühreverdî’nin, bir leğen suyun içinde var ettiği bir dünyada Mısır sultanına evleneceği kadını aratması konulu minyatürler (G. 14, G. 15) keramet ikonografisine aittir.

\section{Sonuç}

Kırk Vezir Hikâyeleri'nin İstanbul ve Uppsala nüshasındaki minyatürler üslup özellikleri açısından, Nakkaş Osman ve onunla birlikte çalışan sanatçıların, Osmanlı sarayı için resimlediği Şehinşahnâme I. [İ̈KK F. 1404] ve Surnâme-i Hümayun'un [TSMK, H.1344] tasvirleriyle benzerlik göstermektedir. Bu iki eserin sırasıyla 1581 ve 1582 yıllarına ait olması Kırk Vezir Hikâyeleri'nin tarihsiz İstanbul nüshasının da 1580'li yıllarda hazırlanmış olabileceğini düşündürmektedir. Kırk Vezir Hikâyeleri'nin Osmanlı sarayının içinde okunduğuna dair kayıtlar, hem İstanbul nüshası hem de 1586-87 tarihli Uppsala nüshasının Sultan III. Murad döneminde, saray için hazırlanmış olma ihtimalini güçlendirmektedir. Üzerinde III. Selim'e ait vakıf mührünü taşıyan Kırk Vezir Hikâyeleri İstanbul nüshası minyatürleriyle Uppsala nüshası minyatürleri arasındaki ikonografik ortaklık ve üslup benzerliği, iki nüshanın birbirine yakın bir tarihte üretildiği fikrini desteklemektedir.

Kırk Vezir Hikâyeleri'nde bilgeliğin temelini oluşturan adalet kavramı vezirler, hilekârlık ve kötülük de çoğunlukla kadın karakterler tarafından temsil edilmektedir. Peygamber hikâyeleri, tanınmış sufiler, yöneticiler ve filozofların hikâyelerinin anlatıldığı çerçeve hikâye içindeki iç hikâyeler doğru ve iyi davranışların seçilmesinin önemini işaret eden nasihatlerle sonlandırılmaktadır. Bu nasihatlerin içinden süzüldüğ̈ hikâyeleri tasvir eden Kırk Vezir Hikâyeleri minyatürleri, ikonografik açıdan özgündür ve Osmanlı minyatüründe nasihatname ikonografisinin temsilcileridir. Kırk Vezir Hikâyeleri minyatürleri arasında Şeyh Şehabeddin Sühreverd-i Maktül'ü, İbn Sina'yı ve bu iki filozof dışında Gazneli Mahmud ve has adamı Ayaz'1 gösteren sahneler sadece Osmanlı minyatürü değil, İslam resmi açısından özgün örneklerdir. 
Hakem Değerlendirmesi: Dış bağımsız.

Çıkar Çatışması: Yazar çıkar çatışması bildirmemiştir.

Finansal Destek: Yazar bu çalıșma için finansal destek almadığını beyan etmiștir.

Peer-review: Externally peer-reviewed.

Conflict of Interest: The author has no conflict of interest to declare.

Grant Support: The author declared that this study has received no financial support.

\section{Kaynakça/References}

Apaydın, Yunus. “Adalet Nedir? Mahiyet ve Keyfiyet.” Bilimnâme 35 (2018/1): 267-296.

Bağcı, Serpil, Filiz Çağman ve Günsel Renda ve Zeren Tanındı. Osmanlı Resim Sanatı. İstanbul: Kültür ve Turizm Bakanlığı, 2006.

Bayat, Ali Haydar. "Türk-İslam Toplumlarında İbn Sina Hikâye ve Fıkraları.” Uluslararası İbn Sina Sempozyuтu Bildiriler, Ankara: Kültür ve Turizm Bakanlığı Milli Kütüphane, 1984, 575-585.

Birinci, Aziz. "Kırk Vezir Hikâyeleri İnceleme Metin Sözlük.” Doktora tezi, İstanbul Üniversitesi, 2012.

Bozkurt, Nebi. "Uc b. Unuk.” Türkiye Diyanet Vakfi İslam Ansiklopedisi. 42. İstanbul: Türkiye Diyanet Vakfi, 2012, 34-35.

Deny, Jean. "Shaikhzade.” E. J. Brill's First Encylopedia of Islam 1913-1936. 8. Leiden: E. J. Brill, 1987,284

Erünsal, İsmail. Kütüphanecilikle İlgili Metinler ve Belgeler. 2 cilt. İstanbul: İstanbul Üniversitesi Edebiyat Fakültesi Yayınları, 1982.

Fetvac1, Emine. Sarayın Imgeleri Osmanlı Sarayının Gözüyle Resimli Tarih. Çev. Nurettin Elhüseyni. İstanbul: Yap1 Kredi Yayınları, 2013.

Fidan, Gülşah Gaye. "Sinbadnâmelerden Hareketle Çerçeve Hikâye Geleneğinde Metinlerarasılık: Tutî Hikâyesi Örneği. ” Divan Edebiyatı Araştırmaları Dergisi 8 (2012): 67-88.

Fisher C. G. ve A.W. Fisher. "Topkapı Saray1 in the Mid-Seventeenth Century: Bobovi's Decription." Archivum Ottomanicum Anno 10, 1985 [1987]: 5-83.

Gibb, Elias John Wilkinson. The History of Forty Vezirs or The Story of The Forty Morns and Eves. London: Lowe Brydone, 1886.

İlhan Kutluer. "Sühreverdî Maktül." Türkiye Diyanet Vakfi Íslam Ansiklopedisi. 38. İstanbul: Türkiye Diyanet Vakfi, 2010, 36-40.

İz, Fahir. Eski Türk Edebiyatı'nda Nesir XVI ve XIX. Yüzyıl Ortasına Kadar Yazmalardan Seçilmiş Metinler. İstanbul: Osman Yalçın Matbaası, 1964.

Gutmann, Joseph ve Vera Basch Moreen. "The Combat Between Moses and Og in Muslim Miniatures." Bulletin of The Asia Institute I (1987): 111-122.

Kafesoğlu, İbrahim. " Mahmud Gaznevî.” İslam Ansiklopedisi: İslam Alemi Tarih, Coğrafya, Etnografya ve Biyografya Lugatı. 5/1. İstanbul: Milli Eğitim Bakanlı̆̆1, 1987, 173-183.

Kavruk, Hasan. "Kırk Vezir Hikâyelerinde Kadın.” İstanbul Üniversitesi Edebiyat Fakültesi Türk Dili ve Edebiyatı Dergisi, 30 (2003): 263-303.

Kızıltan, Mübeccel. “Kırk Vezir Hikâyeleri.” Doktora tezi, İstanbul Üniversitesi, 1991.

Kızıltan, Mübeccel. “Kırk Vezir.” Türkiye Diyanet Vakfi İslam Ansiklopedisi. 25. Ankara: Türkiye 
Diyanet Vakfi, 2002, 474-475.

Kut, Günay. Yazma Eserlerde Vakıf Mühürleri. Ankara: Kültür ve Turizm Bakanlığı Yayınları, 1984.

Mahir, Banu. Osmanlı Minyatür Sanatı. İstanbul: Kabalcı Yayınevi, 2005.

Merçil, Erdoğan. "Mahmûd-1 Gaznevî.” Türkiye Diyanet Vakfi İslam Ansiklopedisi. 27. Ankara: Türkiye Diyanet Vakf1, 2003, 362-365.

Muhammed b. Muhammed b. Hüseyin Mevlânâ Celaleddin-i Rumî, Mesnevi Tercümesi ve Şerhi. Tercüme ve Şerh Abdülbaki Gölpınarlı. V-VI cilt. İstanbul: İnkılap ve Aka Kitabevleri, 1984.

Onay, Ahmet Talat. Eski Türk Edebiyatında Mazmunlar ve İzahı. Haz. Cemal Kurnaz. Ankara: Türkiye Diyanet Vakfi, 1993.

Renda, Günsel. "Sinbadnama: An Early Ottoman Illustrated Manuscript Unique in Iconography and Style.” Muqarnas 21 (2004): 311-322.

Sazyek, Hakan. Roman Terimleri Sözlüğü Roman Sanatından Yüz Terim. Ankara: Hece Yayınları, 2015.

Şenocak, Ebru. "Halk Muhayyilesinde İbn Sina ve Hayatı Hakkında Anlatılan Efsaneler." Akra Kültür Sanat ve Edebiyat Dergisi 8 (2016): 159-168.

Tanındı, Zeren. "Sultanlar, Şairler ve İmgeler; Şehnâme-i Firdevsî’nin Mukaddimesi’nin Resimleri." İstanbul Üniversitesi Sosyal Bilimler Dergisi 15 (2008/2): 267-296.

Timurtaş, F. Kadri. “Türkiye Edebiyatı.” Türk Dünyası El Kitabı Ankara: Türk Kültürünü Araştırma Enstitüsü Yayınları, 1976.

Tornberg, Carows Johannes. Codices Arabici, Persici et Turcici Bibliotecae Regiae Universitatis Upsaliensis. Osnabrick: Biblio Verlag, 1988.

Uludağ, Süleyman. Tasavvuf Terimleri Sözlüğü. İstanbul: Kabalcı Yayınc1lık, 2012.

Zal, Ünal. "Kırk Vezir Hikâyelerinin Karşılaştırılması (Uppsala ve İstanbul Metinleri).” Turkish Studies 10/12 (2015): 1275-1318.

Kırk Vezir Hikâyeleri. İstanbul Üniversitesi Kütüphanesi, T. 7515, 1a-160a.

Kırk Vezir Hikâyeleri. Uppsala Üniversitesi Kütüphanesi, Vet.38, 1a-164a.

https:/www.alvinportal.org/alvin/view.jsf?dswid=7475\&searchType=EXTENDED\&query=+fort $\mathrm{y}+$ viziers\&aq $=\% 5 \mathrm{~B} \% 5 \mathrm{~B} \% 7 \mathrm{~B} \% 22 \mathrm{~A} \_\mathrm{FQ} \% 22 \% 3 \mathrm{~A} \% 22+$ forty+viziers $\% 22 \% 7 \mathrm{D} \% 5 \mathrm{D} \% 5 \mathrm{D} \&$ aqe $=\% 5 \mathrm{~B} \% 5 \mathrm{D} \& \mathrm{af}=\% 5 \mathrm{~B} \% 5 \mathrm{D} \& \mathrm{pid}=$ alvin-record $\% 3 \mathrm{~A} 14015 \& \mathrm{c}=1 \#$ alvin-record $\% 3 \mathrm{~A} 14015$ Erişim Tarihi 08.02.2019. 
